\title{
ÆUSGS
}

science for a changing world

Prepared for the National Park Service

\section{Marine Benthic Habitat Mapping of Muir Inlet, Glacier Bay National Park and Preserve, Alaska}

With an Evaluation of the Coastal and Marine Ecological Classification Standard III

By Luke D. Trusel, Guy R. Cochrane, Lisa L. Etherington, Ross D. Powell, and Larry A. Mayer

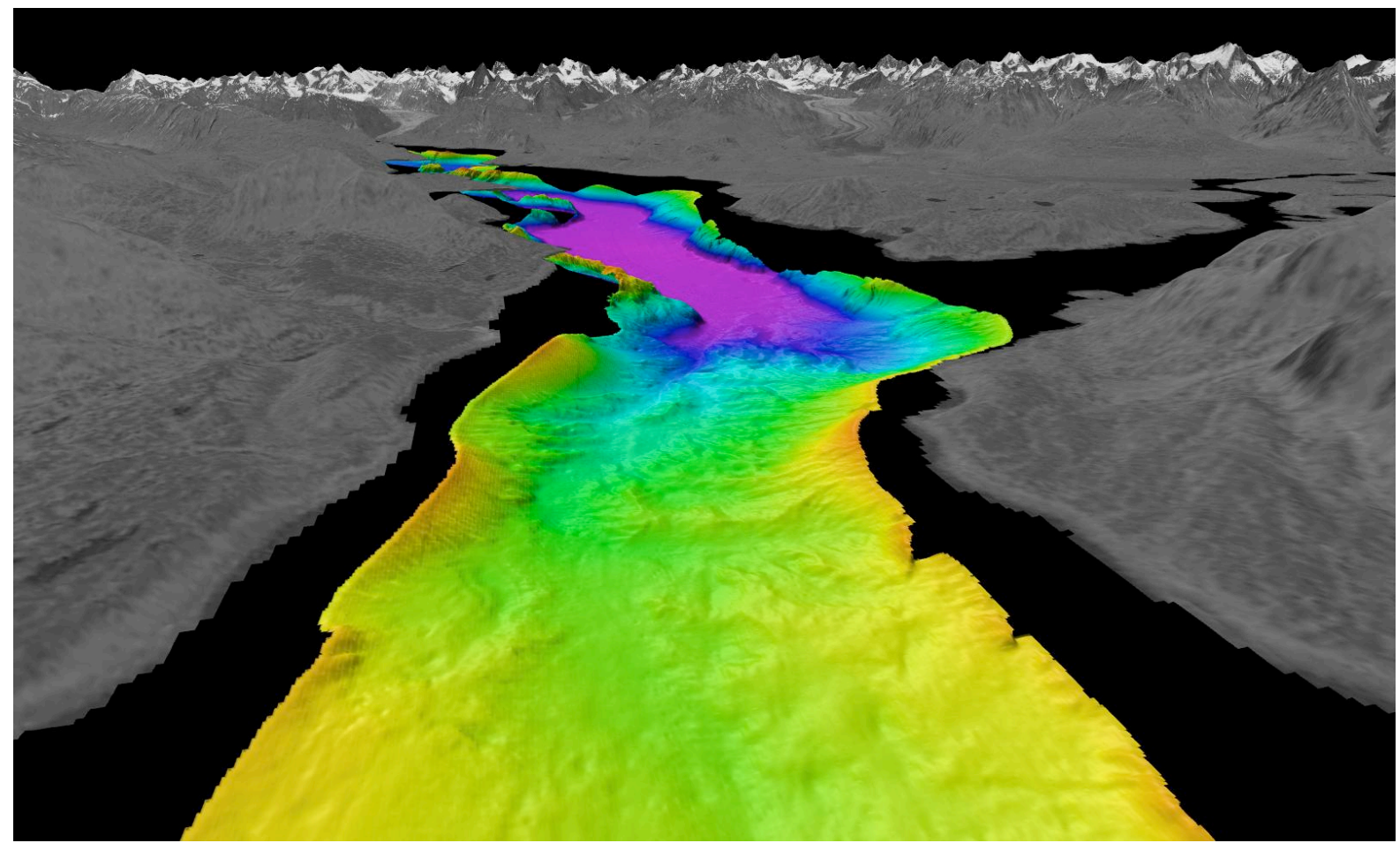

Perspective view of bathymetry and topography of Muir Inlet looking north from Glacier Bay.

Pamphlet to accompany

Scientific Investigations Map 3122

U.S. Department of the Interior

U.S. Geological Survey 


\section{Contents}

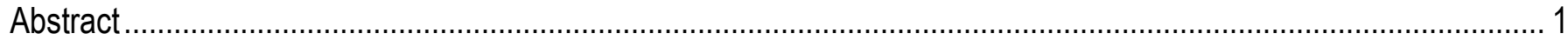

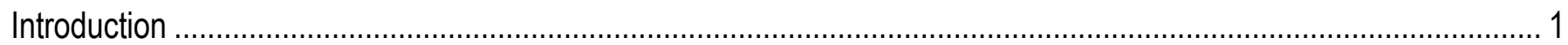

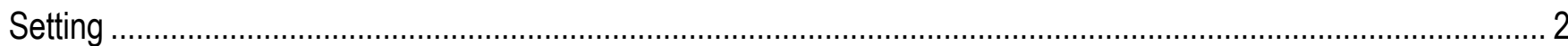

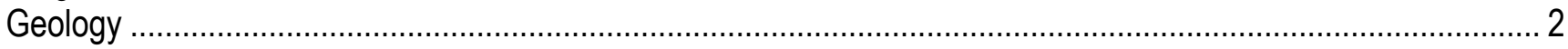

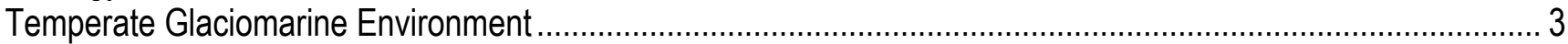

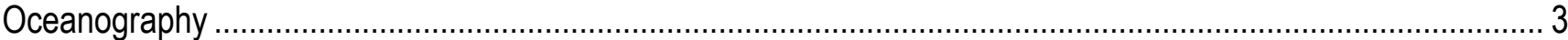

Previous Habitat Mapping in Glacier Bay ................................................................................................... 4

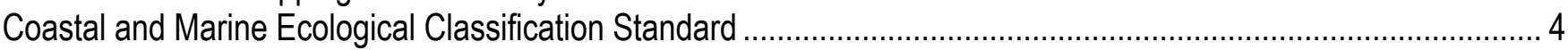

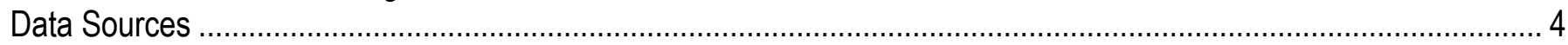

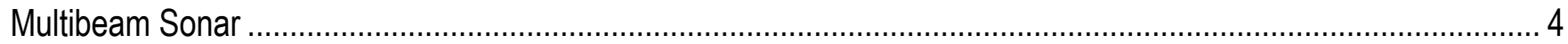

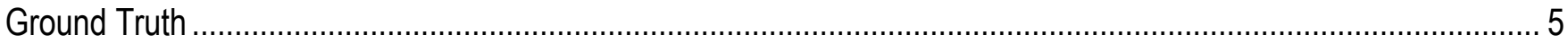

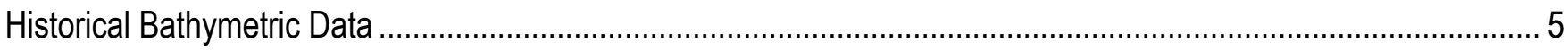

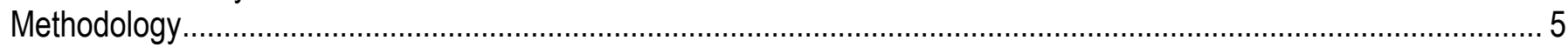

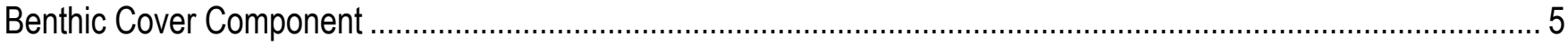

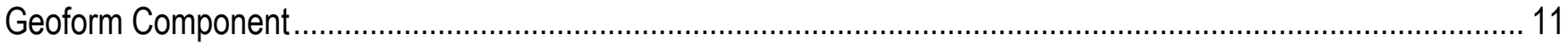

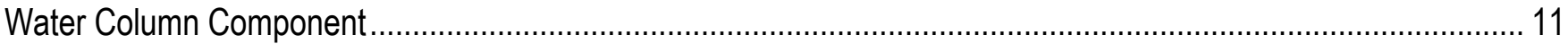

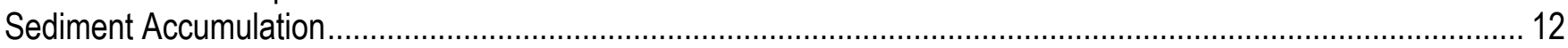

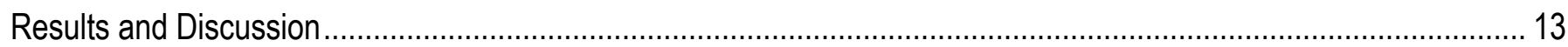

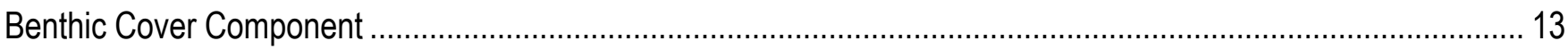

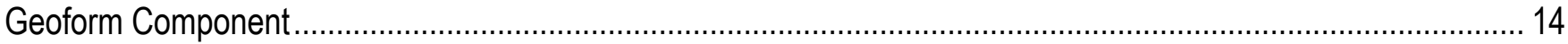

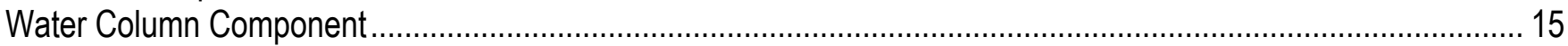

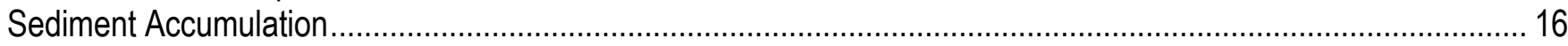

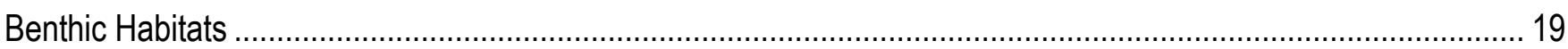

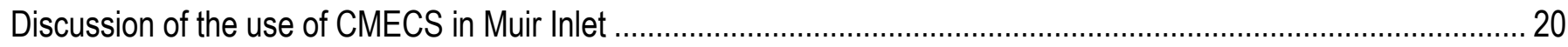

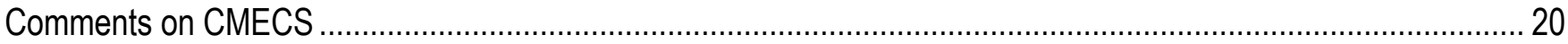

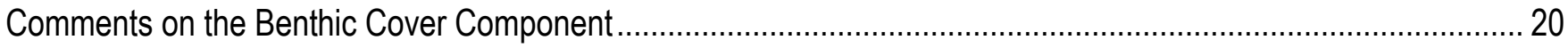

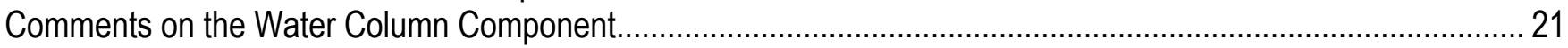

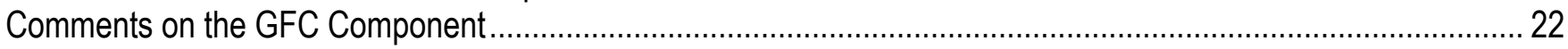

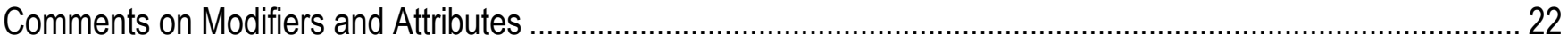

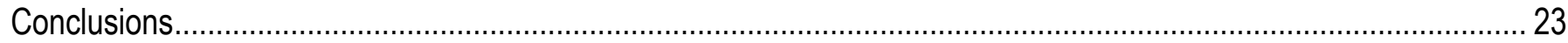

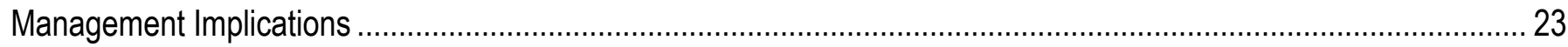

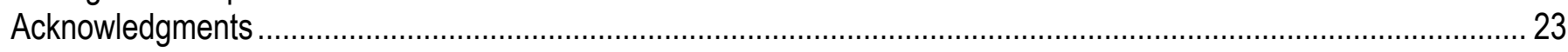

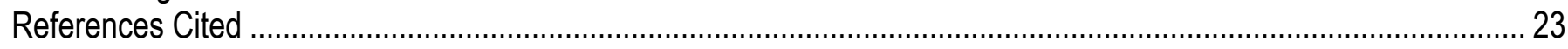

\section{Figures}

Figure 1. Location maps for Muir Inlet relative to (A) Alaska and (B) Glacier Bay. ........................................2

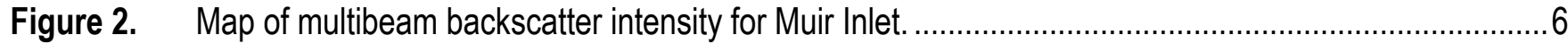

Figure 3. Map of CMECS rugosity classes for Muir Inlet....................................................................... 7

Figure 4. Map of CMECS slope classes for Muir Inlet...............................................................

Figure 5. Perspective view of backscatter draped on bathymetry showing subaerial and submarine bedrock and apparent boulder talus (red outline) at base of slope.............................................................................. 10

Figure 7. Maps showing (A) upper and (B) bottom water column CMECS habitats in Glacier Bay area...........17

Figure 8. Map showing average annual sediment accumulation rates for $1972-2004$............................... 18 


\section{Tables}

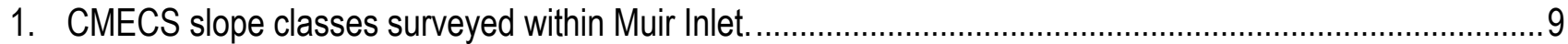

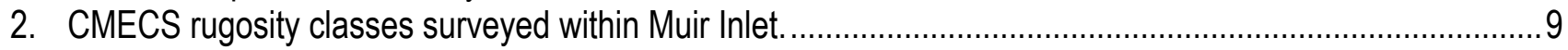

3. CMECS benthic depth zones surveyed within Muir Inlet. .................................................................. 11

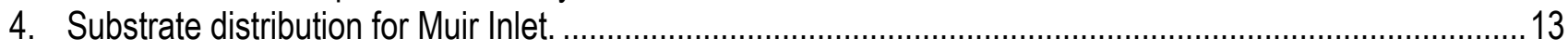

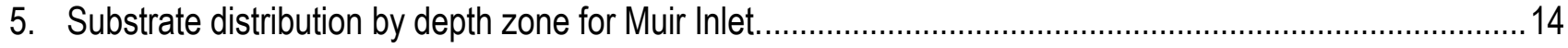

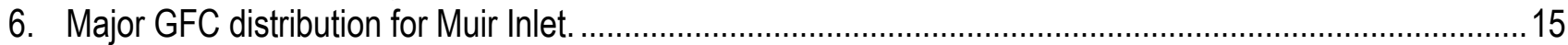

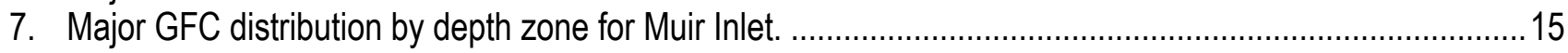




\title{
Marine Benthic Habitat Mapping of Muir Inlet, Glacier Bay National Park and Preserve, Alaska
}

\author{
With an Evaluation of the Coastal and Marine Ecological Classification Standard III
}

\author{
By Luke D. Trusel, Guy R. Cochrane, Lisa L. Etherington, Ross D. Powell, and Larry A. Mayer
}

\begin{abstract}
Seafloor geology and potential benthic habitats were mapped in Muir Inlet, Glacier Bay National Park and Preserve, Alaska, using multibeam sonar, ground-truth information, and geological interpretations. Muir Inlet is a recently deglaciated fjord that is under the influence of glacial and paraglacial marine processes. High glacially derived sediment and meltwater fluxes, slope instabilities, and variable bathymetry result in a highly dynamic estuarine environment and benthic ecosystem. We characterize the fjord seafloor and potential benthic habitats using the Coastal and Marine Ecological Classification Standard (CMECS) recently developed by the National Oceanic and Atmospheric Administration (NOAA) and NatureServe. Substrates within Muir Inlet are dominated by mud, derived from the high glacial debris flux. Water-column characteristics are derived from a combination of conductivity temperature depth (CTD) measurements and circulation-model results. We also present modern glaciomarine sediment accumulation data from quantitative differential bathymetry. These data show Muir Inlet is divided into two contrasting environments: a dynamic upper fjord and a relatively static lower fjord. The accompanying maps represent the first publicly available high-resolution bathymetric surveys of Muir Inlet. The results of these analyses serve as a test of the CMECS and as a baseline for continued mapping and correlations among seafloor substrate, benthic habitats, and glaciomarine processes.
\end{abstract}

\section{Introduction}

This study is a bottom-up approach to mapping benthic habitats (Greene and others, 2007) in Muir Inlet (fig. 1). Seafloor substrate and morphology are characterized so that they may be correlated to and associated with a specific set of benthic conditions favorable for local biota. These biota include both commercially and recreationally important species such as king crabs (Paralithodes camtschaticus), Tanner crabs (Chionoecetes bairdi), and Pacific halibut (Hippoglossus stenolepis) (Mondragon and others, 2007a,b). Seafloor substrates and, therefore, potential benthic habitats were mapped at depths ranging from just below the surface to greater than $300 \mathrm{~m}$ in the deepest fjord basins. The substrate was characterized by using a combination of high-resolution multibeam bathymetry and backscatter imagery, numerous ground-truth sources, and knowledge of the local fjord environment.

In early June 2004, nearly $75 \mathrm{~km}^{2}$ of multibeam-sonar mapping was completed in Muir Inlet aboard the $R / V$ Maurice Ewing during a project funded by the National Science Foundation to investigate marine paleoclimate and paleoceanographic records in southern Alaska. Multibeam records were supplemented with seismic reflection profiles and several sediment cores. Analyses from this cruise, thus far, have focused on tidewater-glacier dynamics and history inferred through glacial-sequence stratigraphy (Cowan and others, 2008) and reconstruction of glacial discharge dynamics from rhythmic sedimentary deposits (Jackolski and others, 2006). Ongoing research includes analyses of deglaciation processes inferred from submarine glacial landforms (Trusel and others, 2009) and measurements of glacial-sediment volumes and inferred sediment yields and erosion rates (Trusel and others, 2008).

The multibeam bathymetric (sheet 1 ) and acoustic backscatter data are combined with additional information in an Environmental Systems Research Institute $\left(\mathrm{ESRI}^{\mathrm{TM}}\right.$ ) Geographic Information Systems (ArcGIS ${ }^{\mathrm{TM}}$ ) database to create several geospatial products. The National Oceanic and Atmospheric Administration (NOAA) and NatureServe's CMECS (Madden and others, 2008) was used to classify seafloor substrate (sheets 2 and 3), potential benthic habitats, water column properties, and seafloor geomorphology (sheet 4). An estimate of modern sediment flux measurements using quantitative differential bathymetry is also presented. These geospatial products are the first high-resolution bathymetric surveys for Muir Inlet, serve as baselines for further research, and provide data for park management. 


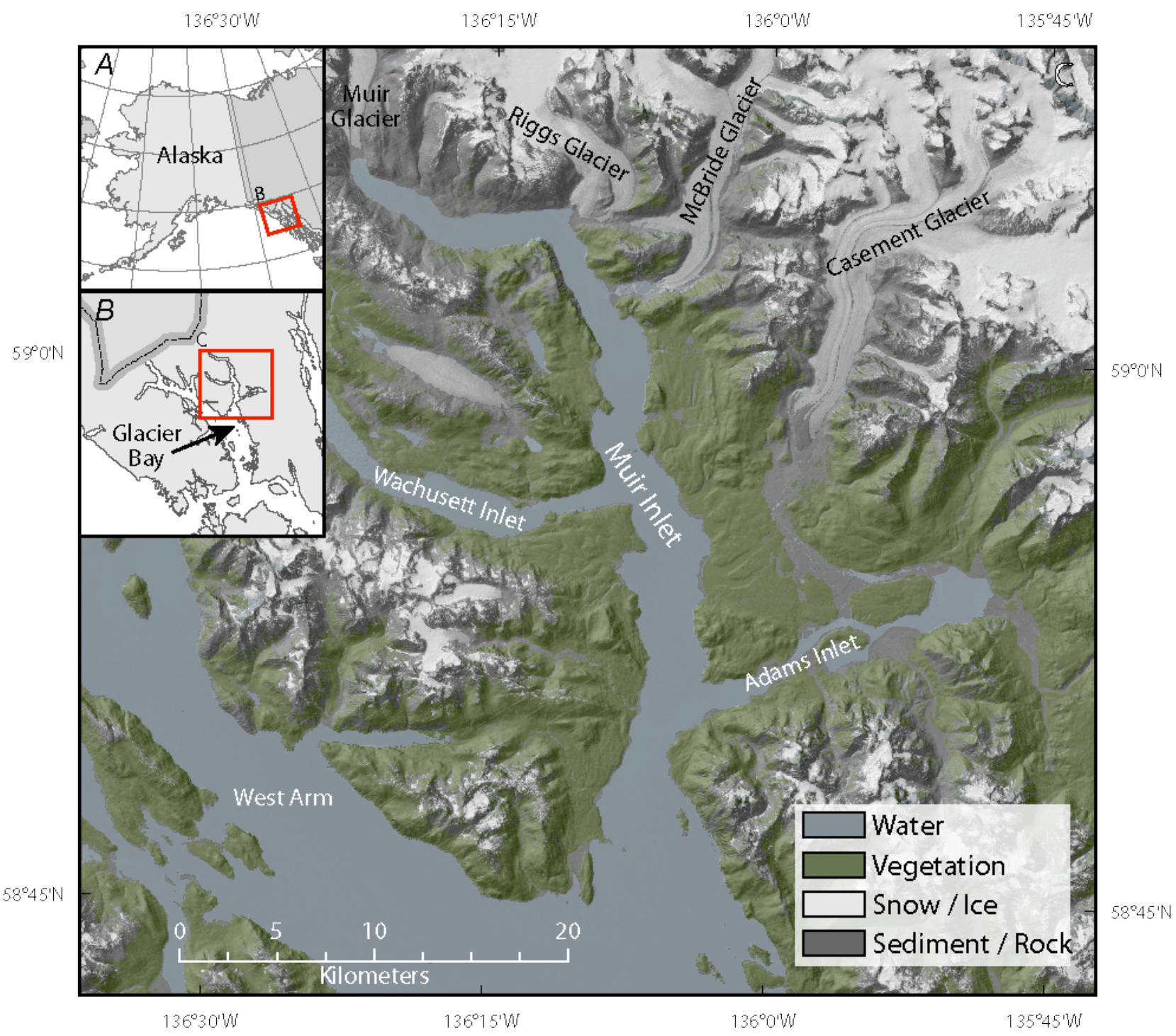

Figure 1. Location maps for Muir Inlet relative to (A) Alaska and (B) Glacier Bay.

\section{Setting}

Glacier Bay National Park and Preserve is located in southeastern Alaska (fig. 1). It is a fjord system that bifurcates into two main northern tributaries: the West Arm and Muir Inlet, also locally called the East Arm. Muir Inlet, the 41-km-long, 1- to 4-km-wide fjord, has recently undergone well-documented, rapid deglaciation (Field, 1947; Powell, 1984; Hall and others, 1995; Seramur and others, 1997). Muir Inlet is a highly dynamic estuarine environment due to the dynamic conditions of deglaciation, sedimentation, and vigorous tidal currents - forces that affect seafloor stability and constantly shape benthic environments. These diverse conditions also host productive food webs; recreational, commercial, and subsistence fisheries; large populations of marine mammals and seabirds; and vessel-based tourism (Piatt and Gende, 2007).

\section{Geology}

Glacier Bay is surrounded by three large mountain ranges - the Chilkat Range to the east, the Takhinsha Mountains in the north, and the Fairweather Range to the west - that separate the fjord system from the Gulf of Alaska. The park is set in a tectonically active area near several active fault systems including the Chilkat-Chatham Strait Fault to the east, the Queen Charlotte-Fairweather Fault to the west, and the Border Ranges Fault that runs through parts of the West Arm (Powell, 1984). Upper Glacier Bay is undergoing glacial isostatic uplift at a rate of $25 \mathrm{~mm} / \mathrm{yr}$ due to post-Little Ice Age ice loss (Larson and others, 2004). The regional bedrock geology is complex and contains a range of rock types and origins, including 
metasedimentary rocks intruded by younger granitic plutons. Geological units exposed at the surface surrounding Muir Inlet are dominated by Paleozoic metasedimentary bedrock and include Silurian, Devonian, and Permian metasedimentary rocks; Tertiary and Cretaceous granite, granodiorite, and diorite; and abundant Quaternary sediment (Powell, 1984).

\section{Temperate Glaciomarine Environment}

The cool-temperate maritime climate of southeast Alaska combined with very high, tectonically active mountain ranges permits widespread glaciation at a relatively low latitude (Wilson and Overland, 1987). Abundant snow falls on surrounding mountain ranges and feeds many valley glaciers that flow into Glacier Bay and are among the largest and most active in southeast Alaska. The glaciers of this region are temperate glaciers, characterized by seasonally abundant meltwater that carries high sediment loads to produce large depositional landforms, both subaerial and submarine (Goldwait, 1974; Powell, 1991; Hunter, 1994). Significant research has focused on the rich glaciomarine sedimentary record within Glacier Bay and yielded insight into complex glaciomarine processes (Powell, 1991; Hunter and others, 1996; Cowan and others, 1999) and the history and processes of deglaciation (Seramur and others, 1997).

Glacial sediment fluxes from the temperate glaciers in southeast Alaska are among the highest recorded worldwide (Powell and Molnia, 1989; Hallet and others, 1996; Elverhøi and others, 1998). In fact, data show that glacial melting can result in sediment accumulation rates in excess of $80 \mathrm{~m} / \mathrm{yr}$ at glacial termini (Powell, 1991; Hunter and others, 1996; Cai and others, 1997; Seramur and others, 1997), which decrease very rapidly with distance (Syvitski, 1989). A complete understanding of these high rates is important because of their potential paleoclimatic significance (Cowan and Powell, 2007), their affect on glacier stability (Powell, 1991), and their potential to act as a major physical control on the diversity and spatial distribution of fjord biota (Carney and others, 1999; Wlodarska-Kowalczuk and Pearson, 2004).

Deglaciation in the region after the Little Ice Age occurred at some of the highest rates documented worldwide. Nearly $100 \mathrm{~km}$ of glacier retreat during the past two centuries has created a network of canals, moraines, outwash complexes, and large volumes of glaciomarine sediment. Recent glacier retreat measured by satellite imagery reveals that Muir Glacier retreated more than $7 \mathrm{~km}$ between 1970 and 1995 (avg $0.28 \mathrm{~km} / \mathrm{yr}$; Hall and others, 1995). Retreat was even faster in the deeper basins within Muir Inlet and peaked near $2 \mathrm{~km} / \mathrm{yr}$ as the glacier retreated from the fjord entrance sill. Several glaciers, including Muir Glacier, Riggs Glacier, and McBride Glacier, formed a confluent tidewater-glacier complex that terminated at the mouth of Muir Inlet between 1860 and 1899. Today, however, Muir and Riggs Glaciers have retreated as much as $50 \mathrm{~km}$, no longer terminate at tidewater, and are separated from the fjord by ice-contact deltas. McBride Glacier remains the only glacier within Muir Inlet still at tidewater but has retreated into McBride inlet, an eastern tributary to the fjord.

\section{Oceanography}

The oceanographic setting of Glacier Bay is also complex, owing to the concurrence of bathymetric variability, tidal currents, and strong seasonal stratification resulting from high rates of glacial ablation, snow melt, and precipitation (Hooge and Hooge, 2002; Etherington and others, 2007b). The morphology of Muir Inlet is characteristic of a glacial fjord and includes a shallow sill topped with a glacial-morainal-bank complex at its mouth (Seramur and others, 1997), steeply sloping walls as steep as $77^{\circ}$, and multiple deep basins separated by transverse sills and morainal banks.

Areas of shallow bathymetry influence tidal current velocity and vertical mixing (Etherington and others, 2007b). In contrast, deep basins are highly stratified in the pelagic environment and have minimal benthic currents. Average root-meansquare (RMS) current speeds (derived from an advanced circulation, or ADCIRC, tidal circulation model) for the main stem of Muir Inlet are low, ranging from 0.01 to $0.139 \mathrm{~m} / \mathrm{s}$. However, peak instantaneous velocities are approximately 50 percent to 100 percent higher than RMS velocities, particularly over areas of shallow bathymetry (Etherington and others, 2007b; Hill, 2007). The narrow constriction in the lower portion of Adams Inlet generates some of the strongest currents in Glacier Bay and the resulting higher rates of mixing (Hill, 2007; Hill and others, 2009). Model results demonstrate the large tidal range within Glacier Bay: values average $3.86 \mathrm{~m}$ at the lowest portions of the bay, increase with distance up the arms of the bay, and reach an average of $4.59 \mathrm{~m}$ at the head of the inlets (Hill, 2007; Etherington and others, 2007b). The highest tides in the bay are found in Adams Inlet (Hill, 2007). Glacier Bay exhibits mixed tides of two high and two low tides per day that have varied amplitude (Etherington and others, 2007b).

Freshwater input at the head of the fjord is a dominant driver of water-column stratification (Etherington and others, 2007b). Spatial and seasonal variability are greatest for salinity and stratification and are directly associated with freshwater flux (Etherington and others, 2007b; Hill and others, 2009). This flux peaks between June and October at about $1,000 \mathrm{~m}^{3} / \mathrm{s}$ for the entire Glacier Bay watershed (Hill and others, 2009). The summer discharge peak coincides with peak stratification, peak water temperature, minimum surface salinity, and generally higher chlorophyll $a$ concentrations (Etherington and others, 2007b). Similarly, peak glaciomarine sediment flux also occurs during the summer months as a result of enhanced subglacial stream discharge (Cowan and Powell, 1990).

Freshwater flux from glacial ablation in southeast Alaska is important both to local fjord conditions (Etherington and others, 2007b; Hall and others, 2009) and to a global contribution of 15 percent to present-day eustatic sea-level rise (Meier and others, 2007). The thinning of southeastern Alaskan glaciers contributed $0.04 \pm 0.01 \mathrm{~mm} / \mathrm{yr}$ to global sea-level rise in the latter 
part of the $20^{\text {th }}$ century (Larson and others, 2007). More recently, mass loss from the these glaciers was found to contribute $0.23 \pm 0.01 \mathrm{~mm} / \mathrm{yr}$ to global sea level rise for the period April 2003-March 2007 (Luthcke and others, 2008).

\section{Previous Habitat Mapping in Glacier Bay}

Several benthic-habitat-mapping initiatives have been completed in Glacier Bay. In 2001, the United States Geological Survey (USGS) collected multibeam bathymetry for this area (Carlson and others, 2002). In 2004, seafloor video observations and sediment samples were collected, processed, and correlated with existing geophysical data, which resulted in a characterization of seafloor morphology, substrate, and habitat distribution following the Greene and others (1999) classification (Harney and others, 2007).

Subsequent research based on these data includes a geological to biological association analysis by Etherington and others (2007a). This work used detrended correspondence analysis (Jonman and others, 1995), a multivariate statistical technique, to examine relations between habitat types and taxa distribution. Etherington and others, (2007a) found substrate type and current exposure to be the dominant control on species distributions in Glacier Bay. Three benthic habitats were identified: (1) shallow-water, high-current sand and cobble habitat associated with urchin, horse mussel, and scallop; (2) deepwater mud habitat associated with gastropod, algae, flatfish, Tanner crab, shrimp, sea pen, and other crustaceans; and (3) moderate-depth cobble and mud habitat associated with sea star, rockfish, sculpin, anemone, sea cucumber, worm, pollock/cod, basket star, and other fish (Etherington and others, 2007a).

\section{Coastal and Marine Ecological Classification Standard}

The work presented here serves as a pilot project to evaluate and implement CMECS. CMECS, under development by NOAA and NatureServe, if implemented, will provide a national standard for classification of marine resources that adheres to the Federal Geographic Data Committee Standards (FGDC). CMECS encompasses three individual components that cover all aspects of the marine environment. The benthic cover component (BCC), the primary component, is a hierarchical, scale-based system that describes geomorphological, physico-chemical, and biological compositions of the coastal and marine substrate (Madden and others, 2008). The water column component (WCC) describes the structure, processes, and biology of the water column (Madden and others, 2008). The geoform component (GFC) describes the coastal seafloor geomorphology at different scales (Madden and others, 2008). In CMECS, geomorphological features are called geoforms. Results presented here focus on the BCC and GFC but also include preliminary application of WCC and adhere to the guidelines of CMECS Version III (Madden and others, 2008).

It is important to note that in February 2009 a revised CMECS (Madden and others, 2009) was released with fundamental changes at many framework levels. Modifications to comply with the revised standard are not applied in this study. Some results presented here directly transfer to the 2009 CMECS draft (unconsolidated bottom types). Other results would need more fundamental change, including benthic depth zones, GFC types, and other associated analyses and GIS attributes. A bottom-up approach would be necessary to fully comply with the new draft standard. It should also be noted that the BCC is now termed the surface geology component (SGC) in the 2009 CMECS. Although results are not updated for the revised standard, interpretations presented here mostly transfer to the 2009 CMECS and provide a baseline for future benthic habitat investigations in Muir Inlet.

\section{Data Sources}

\section{Multibeam Sonar}

Benthic habitat and seafloor substrate mapping for Muir Inlet relied on multibeam sonar data that were collected onboard the $R / V$ Maurice Ewing cruise EW0408 on September 7, 2004. A Kongsberg Simrad EM-1002 multibeam echosounder was used to obtain high-resolution bathymetric surveying specific to the shallow-to-intermediate depth of the southern Alaska study locations. The EM-1002 simultaneously collects both bathymetric and coregistered backscatter data, providing information about seafloor morphology and composition. The EM-1002 operated in a fixed $\pm 75^{\circ}$ mode, limited to a $400 \mathrm{~m}$ maximum swath. Navigation was recorded by a C-Nav ultra-high-resolution differential global positioning system with maximum accuracy of $<0.1 \mathrm{~m}$ horizontally and $0.2 \mathrm{~m}$ vertically. Vessel roll, pitch, and heave were recorded with a POS-MV motion sensor. This information was integrated in the Simrad software with water column CTD data, positioning from the C$\mathrm{Nav}$, and offset information between the transducer, antenna, and motion sensor to correct for ship motion and produce accurate depth measurements. A team of University of New Hampshire (UNH) scientists using CARIS HIPS and the CUBE algorithm 
within IVS3D Fledermaus processed the raw onboard data. Further processing of backscatter data was later completed using Geocoder software by Luciano Fonseca of UNH to remove data artifacts and enhance details (Fonseca and Calder, 2005). Data were cleaned for errant points, referenced to mean lower low water (MLLW) by correcting for tide, and finally transformed into depth versus absolute position. The bathymetry and backscatter data were gridded using $5.5 \mathrm{~m}$ and $2.5 \mathrm{~m}$ horizontal grid resolutions, respectively. These data cover about $75 \mathrm{~km}^{2}$ or nearly 70 percent of Muir Inlet, extending vertically from just below sea level to over $300 \mathrm{~m}$ depth in the deepest fjord basins and horizontally from the southern entrance sill to the Muir Glacier delta in the northern reaches.

\section{Ground Truth}

Multiple resources were utilized to aid in classifying the seafloor substrate. These ground-truth sources include USGS seafloor video observations (Harney and others, 2007), sediment samples and cores (Cowan and others, 1999; Hunter, 1994; Jackolski and others, 2006), seismic reflection profiles (Molnia and others, 1984; Seramur and others, 1997; Cowan and others, 1999), seafloor dive observations from other habitat investigations (Stone and others, 2005), abundant aerial and ground-based photography, and a general knowledge of fjord processes from the substantial literature (Powell, 1981; Powell and Molnia, 1989). In particular, an understanding of modern processes active in the glaciomarine environment was fundamental in the interpretation of multibeam backscatter data. USGS video observations that provided the primary ground-truth for benthic habitat mapping in Glacier Bay proper (Harney and others, 2007) were not extensively collected in Muir Inlet and consisted almost entirely of mud substrate observations. Therefore, these other data sources and knowledge of the environment were critical in production of the seafloor character maps.

\section{Historical Bathymetric Data}

Two historical bathymetric datasets were used to measure recent sediment accumulation within Muir Inlet. NOAA National Ocean Service (NOS) hydrographic surveys H09317 and H09318 cover upper and lower portions of Muir Inlet and its tributaries (NOAA, 1972a,b). These surveys were both collected in August and September 1972 aboard the NOAA ship McArthur using Raytheon DE-723 fathometers for depth measurements (NOAA, 1972a, b). Water-column properties were measured for sounding velocity corrections, however, they were found to only affect sounding depths by less than 0.5 percent and, therefore, sounding velocity corrections were not applied (NOAA, 1972a,b). Depth measurements were corrected for tidal state and referenced to MLLW (NOAA, 1972a,b). Locations were determined by visual, three-point sextant fix methods using eleven (NOAA, 1972a) or fifteen (NOAA, 1972b) control stations that had geographic positions determined by a WANG Model 700 Calculator.

\section{Methodology}

\section{Benthic Cover Component}

Seafloor habitats were classified using a supervised manual classification of seafloor substrate based on multibeam backscatter intensity (fig. 2), two derivative bathymetric properties (seafloor rugosity (fig. 3) and slope (fig. 4)), and groundtruth. This approach was chosen as the best method based on the CMECS hierarchy that groups hard-flat (boulder/rubble or pavement) and hard-rugose (bedrock) habitats in the rock-bottom class, and hard-flat (cobble/gravel or shell) and soft-flat (mud) habitats in the unconsolidated-bottom class. Therefore, this classification could not be reliably completed with a supervised maximum likelihood classification method (Cochrane, 2008), because of the inability without extensive groundtruth to create confident statistical signatures that discern hard-flat substrate in both rock bottom and unconsolidated bottom CMECS classes.

Multibeam backscatter data were smoothed to reduce noise and artifacts in the data using a $3 \times 3$ neighborhood filter to average cells. This filtered backscatter grid was reclassified into two induration (seafloor hardness) classes. A relatively high backscatter reflectance value was chosen such that areas known to be bedrock were classified as rock bottom and areas known to be mud were classified as unconsolidated bottom.

Two derivative properties from the multibeam bathymetry data were used to further classify substrate: seafloor rugosity (fig. 3) and seafloor slope (fig. 4). Seafloor rugosity was calculated using the methods of Jenness (2003) as implemented in the Benthic Terrain Modeler software (Wright and others, 2005). Rugosity is a dimensionless measure of seafloor roughness or its actual surface area divided by its planar area. Therefore, a completely flat surface has a rugosity of exactly 1. In general, a higher rugosity is characteristic of rough substrates including rocky areas. Similarly, lower rugosity is 


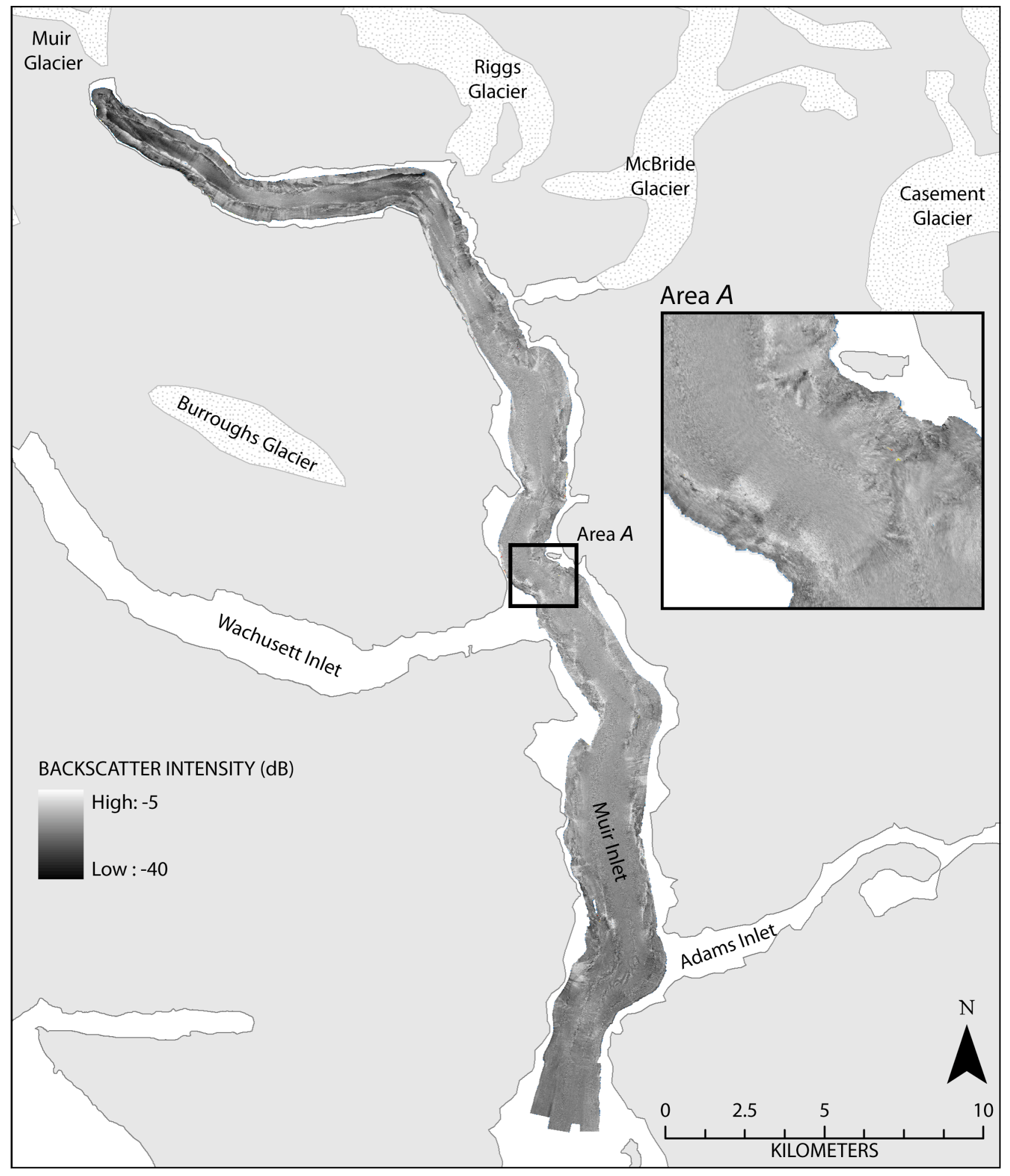

Figure 2. Map of multibeam backscatter intensity for Muir Inlet. 


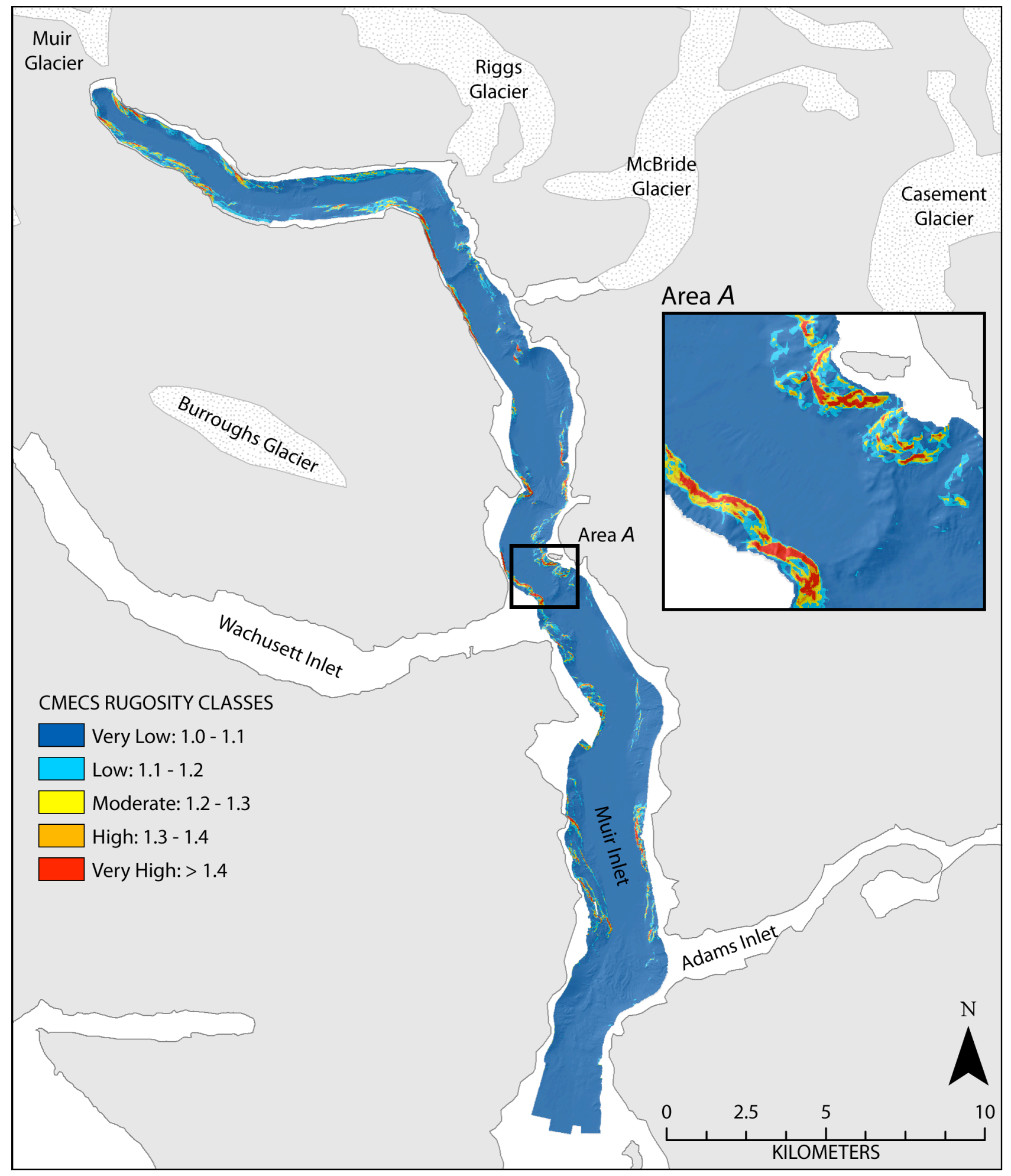

Figure 3. Map of CMECS rugosity classes for Muir Inlet. 


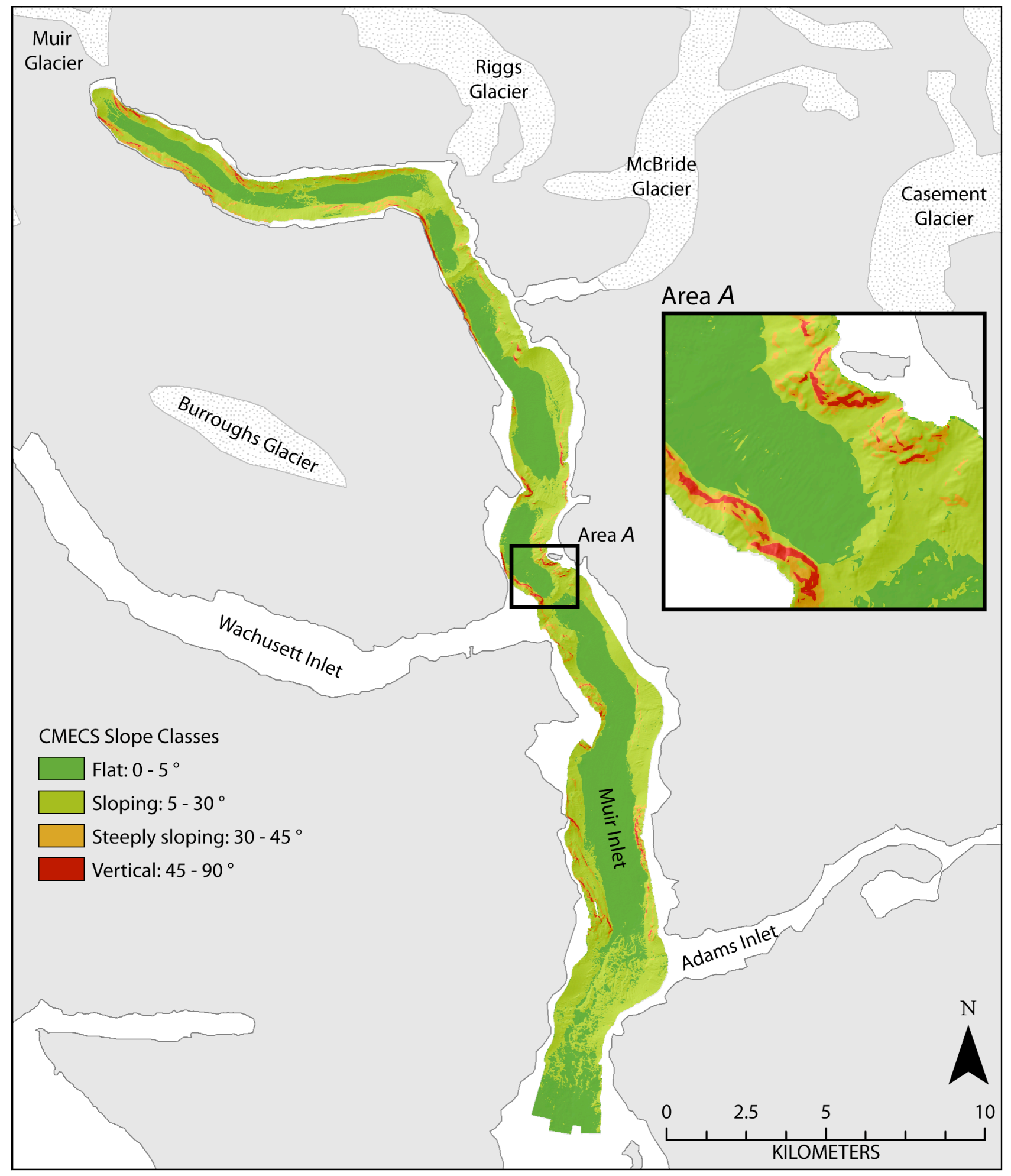

Figure 4. Map of CMECS slope classes for Muir Inlet. 
characteristic of flat, less complex soft bottom substrate. Because of sediment instability on steep slopes, areas with very high slope are often consolidated glacial material or bedrock, whereas low sloping areas are the loci of soft-sediment deposition and redeposition from slope failures and sediment gravity flows from fjord walls.

Rugosity and slope rasters were both reclassified into groups according to CMECS such that areas with similar rugosity or slope are combined into classes (table 1,2). Rugosity is a somewhat qualitative measurement that is biased based on the resolution of the bathymetry, that is, a rugosity value obtained with $5 \mathrm{~m}^{2}$ resolution will be different for the same area using $10 \mathrm{~m}^{2}$ bathymetry data. Therefore, rugosity classes may be altered in specific applications to better represent the data (Greene and others, 2007). We chose to modify the CMECS classes to better represent variability within our rugosity measurements (table 1).

Table 1. CMECS slope classes surveyed within Muir Inlet.

\begin{tabular}{llll}
\hline \multicolumn{1}{c}{ Slope } & \multicolumn{1}{c}{ Vertical angle ${ }^{1}$} & $\begin{array}{c}\text { Percentage of } \\
\text { total area }\end{array}$ & Area $\left(\mathbf{k m}^{2}\right)$ \\
\hline Flat & $0-5^{\circ}$ & 47.9 & 34.7 \\
Sloping & $5-30^{\circ}$ & 45.7 & 33.1 \\
Steeply sloping & $30-45^{\circ}$ & 5.1 & 3.7 \\
Vertical & $4-90^{\circ}$ & 1.3 & 0.9 \\
Overhang $^{\circ}$ & $>90^{\circ}$ & 0 & 0 \\
\hline
\end{tabular}

${ }^{1}$ The greatest slope measured in Muir Inlet was $76.7^{\circ}$.

Table 2. CMECS rugosity classes surveyed within Muir Inlet.

\begin{tabular}{llll}
\hline \multicolumn{1}{c}{ Rugosity types } & \multicolumn{1}{c}{ Values $^{1}$} & $\begin{array}{c}\text { Percentage of } \\
\text { total area }\end{array}$ & \multicolumn{1}{c}{ Area $\left(\mathbf{k m}^{2}\right)$} \\
\hline Very low & $1-1.1$ & 90.4 & 65.6 \\
Low & $1.1-1.2$ & 5.9 & 4.3 \\
Moderate & $1.2-1.3$ & 1.8 & 1.3 \\
High & $1.3-1.4$ & 0.8 & 0.6 \\
Very high & $>1.4$ & 1.1 & 0.8 \\
\hline \multicolumn{4}{r}{ 1 Modified rugosity values based on Madden and others (2008) and Greene and others (2007). }
\end{tabular}

Reclassified rasters of induration, rugosity, and slope were converted to polygons and merged into one shapefile using the ArcView union function, which allows for selection of polygonal areas based on specific attributes. Areas of vertical slope and very high rugosity (defined by CMECS) initially classified as unconsolidated bottom were investigated, and if supported by geological reasoning and ancillary information, these areas were changed to rock bottom. Similarly, areas classified as rock bottom because of high backscatter but with a flat slope and very low rugosity (defined by CMECS), such as the nadir area (fig. 5), were investigated and changed to unconsolidated bottom if reasonable. Multiple iterations of these steps in stepwise higher and (or) lower CMECS classes of rugosity and slope were completed and investigated subjectively at very fine scale levels, taking into account all available information, including backscatter intensity, seafloor morphology, and information from ground-truth and geological reasoning. The result of this process is the CMECS abiotic class-level substrate map with unconsolidated bottom (CMECS code UB) and rock bottom (CMECS code RB).

Further classification was completed in the benthic cover component down to the subclass level where unconsolidated bottom was divided into mud (CMECS code UB.3), mixed sediments (CMECS code UB.6), and cobble/gravel (CMECS code UB.1). Rock bottom was further divided into bedrock (CMECS code RB.1) and boulder/rubble (CMECS code RB.3). Considering the extreme predominance of glaciomarine sedimentation in Muir Inlet and ground-truth that confirmed substrates dominated by mud (silt and clay) for all basin floor areas, the unconsolidated bottom class was first characterized as entirely mud. We assume that most areas in Muir Inlet are veiled in mud, an inference supported by uniform backscatter data in many areas. Lacking abundant physical samples or imagery of any soft-bottom material other than mud, geological reasoning was used to classify other unconsolidated bottom subclasses. Numerous side-input fluvial sources enter Muir Inlet to form fjord-edge deltas. Transport channels on the delta slopes are evident in the backscatter as having a higher intensity relative to the surrounding cover. We assume most of these deltaic sources transport sand-sized particles into the fjord, although samples are lacking for many locations, and thus these areas were all classified using the CMECS mixed sediments subclass. 


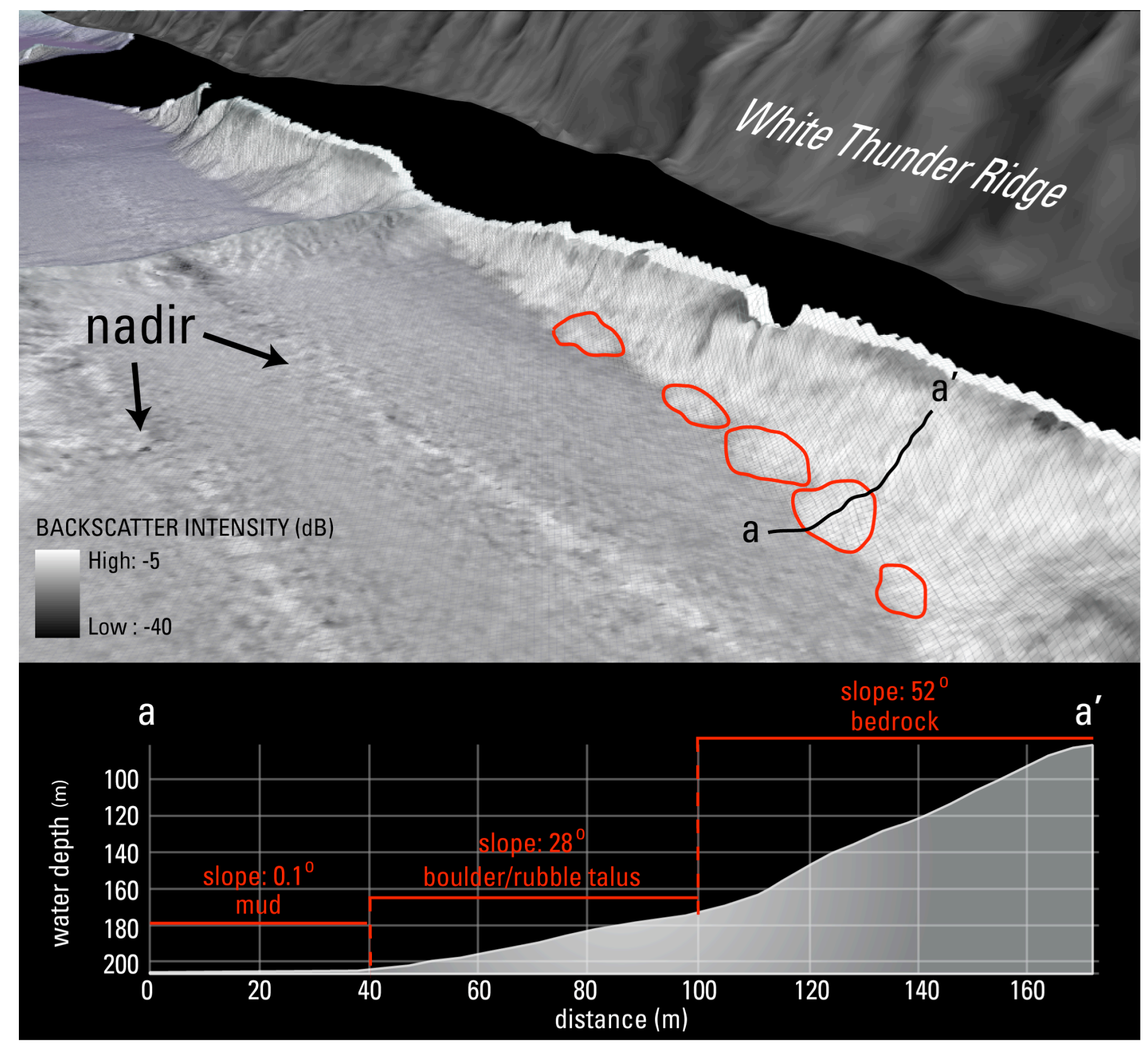

Figure 5. Perspective view of backscatter draped on bathymetry showing subaerial and submarine bedrock and apparent boulder talus (red outline) at base of slope.

One area in lower Muir Inlet that has a very high relative backscatter on the delta slope of an active glacial runoff stream was classified as cobble/gravel, because it represents an area of high and active modern river discharge.

In subclassifying the rock bottom class, all areas were initially assumed to be bedrock. Ground-truth for bedrock areas included seismic reflection data, underwater dive observations from previous research (Stone and others, 2005), and observed transitions from subaerially exposed steep bedrock cliffs to the submarine environment. Areas of apparent submarine talus were identified through fine-scale investigation and classified as boulder/rubble (fig. 5). Most commonly, boulder/rubble exists at the base of submarine bedrock cliffs and is characterized by a lower slope than the bedrock, very high backscatter intensity, and a lobate, splay geometry. These are inferred to form from rock falls and slides that originate both above and below water. 


\section{Geoform Component}

GFC features in Muir Inlet were manually selected from the multibeam bathymetry data using knowledge of glaciomarine processes, the well-documented glacial history in Muir Inlet, and interpretations from other studies (Seramur and others, 1997). Spatial scales defined within the CMECS framework were used to define linear scales using the largest measurable axis. Geoforms were only characterized down to the mesogeoform level (tens of meters to kilometers in size) because of the limited resolution of our bathymetric data. For simplicity, only the largest mesogeoforms are shown on the map on sheet 4; however, the GIS polygon file contains all delineated geoforms. Many areas in Muir Inlet fit into more than one megageoform and mesogeoform class. For example, Muir Inlet lies within the continental margin megageoform, but it is also a fjord megageoform. At the mesogeoform level, a fjord wall is a mesogeoform, but the wall also has multiple mesogeoform scale bedrock outcrops and other features. Therefore, when delineating polygons, it was necessary to create multiple megageoform and mesogeoform categories, which are listed in the GIS table as MEGA_GF, MEGA_GF_2, and so on. While multiple geoforms were selected for each spatial scale, a primary and most informative geoform was chosen for display at each scale; these are listed in the GIS table as DISPMEGAGF and DISPMESOGF. Because all smaller geoforms lie within the fjord megageoform, the primary mesogeoform is shown on the map (sheet 4). The CMECS benthic depth zones (table 3) divide many of these mesogeoforms. To aid in visualization, the color shade of each geoform type gets darker as depth zone increases on the map (sheet 4).

Table 3. CMECS benthic depth zones surveyed within Muir Inlet.

\begin{tabular}{llll}
\hline \multicolumn{1}{c}{ Benthic depth zone } & $\begin{array}{l}\text { Water depth range } \\
\text { (m below sea level) }\end{array}$ & $\begin{array}{c}\text { Percentage of } \\
\text { total area }\end{array}$ & Area $\left(\mathbf{k m}^{2}\right)$ \\
\hline Deep infralittoral & $5-30$ & 0.1 & 0.04 \\
Circalittoral & $30-80$ & 4.1 & 3.0 \\
Circalittoral (offshore) & $80-200$ & 35.5 & 25.7 \\
Mesobenthic & $200-1000$ & 60.3 & 43.8 \\
\hline
\end{tabular}

\section{Water Column Component}

Following the CMECS, water column classes and attributes were assigned to locations of established oceanographic stations within Glacier Bay (Etherington and others, 2007b). Two main data sets were used to define classes and attributes: (1) conductivity temperature depth (CTD) data (Etherington and others, 2007b) and (2) results from a tidal circulation model (Hill and others, 2009; Hill, 2007). Results of the tidal circulation model were used to classify the CMECS attributes of tidal range and energy intensity, whereas the CTD data were used for all other water column attributes. Model predictions of water elevation have been validated against several NOAA stations within Glacier Bay and resulted in strong agreement between predicted and measured values. Model predictions of tidal velocity have been compared with minimum and maximum values of velocity at several NOAA stations within Glacier Bay and the model showed general agreement. CTD data were collected at 22 stations spanning the axes of Glacier Bay from 1993 to 2002 and through all seasons (fig. 6). Parameters include salinity, temperature, density/stratification, turbidity, photosynthetically available radiation, and chlorophyll $a$. Six stations (15-20) span the entire length of Muir Inlet. Detailed computational tidal simulations of Glacier Bay were conducted using an ADCIRC tidal circulation model (Hill, 2007; Hill and others, 2009). ADCIRC output includes time series and global output of watersurface elevation and depth-integrated velocity. To determine a single representative value of tidal-current speed and tidal range at each oceanographic station, the RMS values of speed and tidal elevation were calculated from the results of a harmonic analysis of the model domain (Hill, 2007).

The framework for the CMECS water column component is in draft form, and additional work is needed to refine it and develop the rules for combining classifiers to identify and describe the water-column units (Madden and others, 2008). As a result, we developed our own approach for combining the classifiers and integrating the horizontal and vertical aspects of water column dynamics. The structure of the water column was used to define two vertical strata — upper water layer and bottom water layer - which are defined by those strata above and below the pycnocline, respectively. The pycnocline within Glacier Bay varies both spatially and temporally but generally exists at $15 \mathrm{~m}$ depth or shallower. Because temporal averages were used to define the water-column properties and to simplify the classification of water layers, the upper water layer was defined as 0 $15 \mathrm{~m}$ below the surface while the bottom water layer was the remaining water column below $15 \mathrm{~m}$. This standard definition was 


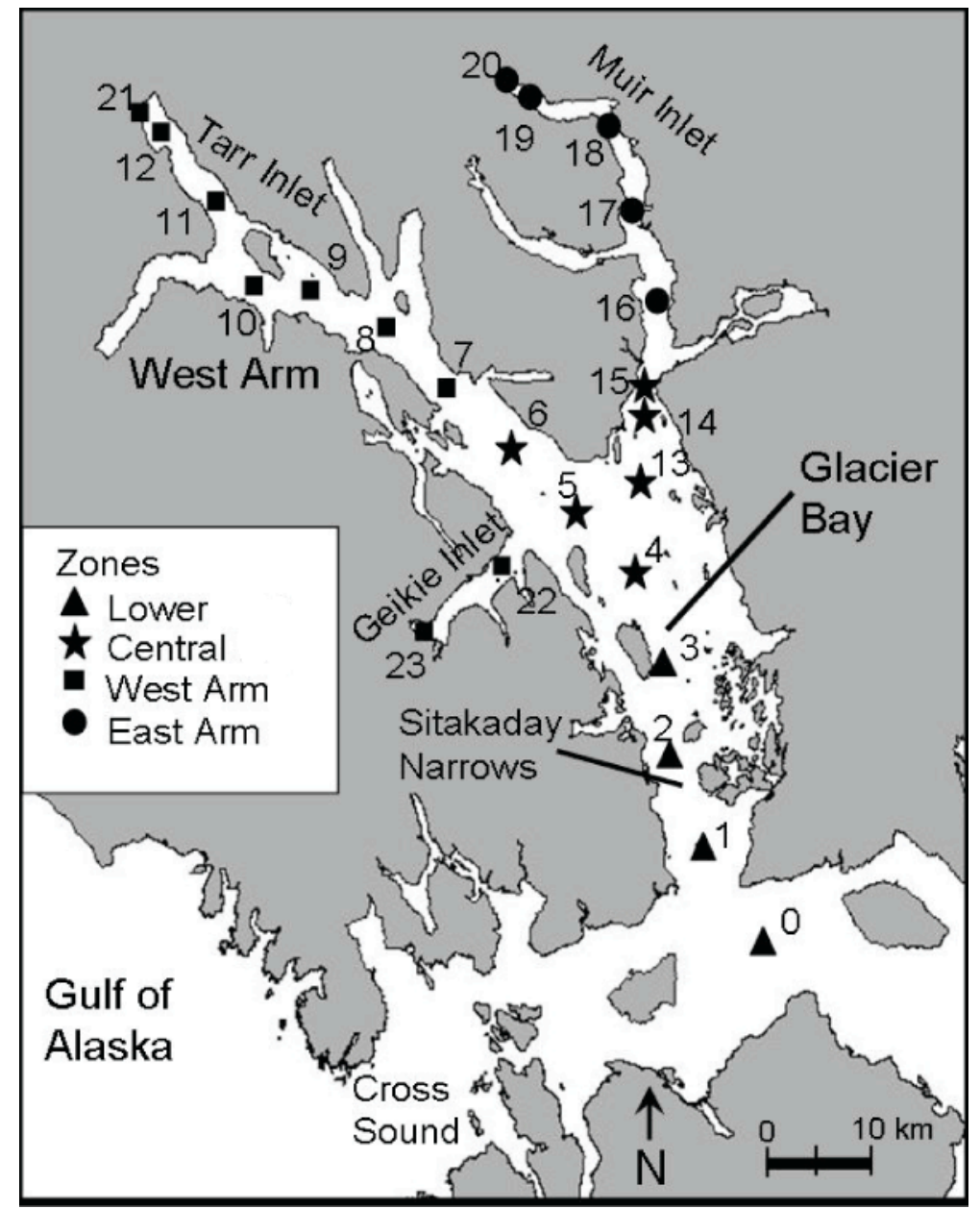

Figure 6. Map showing Glacier Bay oceanographic stations and numbers (adapted from Etherington and others, 2007b).

used for all oceanographic stations of Glacier Bay, and average oceanographic parameter values from 0 to $15 \mathrm{~m}$ were used to classify the upper water layer. CMECS water-column classes and general attributes were applied to the upper water column and bottom water column separately for each of the oceanographic stations. All attributes in which data were available were assessed and classified. Averages of parameters over tidal conditions (ebb/flood, spring/neap) and various time scales (months, years) were used to classify each oceanographic station. The output of tidal velocity from the tidal circulation model is used to classify energy intensity in the upper water column. In shallower areas where vertical mixing is apparent and tidal energy is higher (Etherington and others, 2007b; Hill and others, 2009), bottom energy intensity is assumed to mirror surface energy intensity and depth-integrated velocity values are used to also classify energy intensity in the bottom water column. In deeper areas where stratification is higher and tidal energy is lower (Etherington and others, 2007b; Hill and others, 2009), energy intensity within the bottom water column stratum is classified as no energy. Visual observations of virtually no current motion and accumulation of fine sediments in these deeper areas support this assumption (Etherington and others, 2007a; Harney and others, 2007). Values were only assigned to a point location and were not extrapolated beyond the oceanographic station; thus, only the central regions of the inlets of Glacier Bay were classified. Therefore, the water column classification differs from the GFC and benthic cover classifications, which were based on a comprehensive continuous data set covering almost the entirety of Muir Inlet.

\section{Sediment Accumulation}

Sediment accumulation rates for most of Muir Inlet were calculated using quantitative differential bathymetry. Two bathymetric datasets were used: the 2004 multibeam bathymetry used in this study for seafloor characterization and the 1972 singlebeam bathymetry from NOAA NOS hydrographic surveys. By subtracting the depths from 2004 by those measured in 
1972 and then dividing by the time period, average sediment accumulation rates are calculated. For this study we are interested in modern sedimentation rates because of their potential as a limiting factor in the distribution and diversity of benthic biota (Carney and others, 1999; Wlodarska-Kowalczuk and Pearson, 2004), however this dataset is used elsewhere for analyzing sediment transport and quantifying glaciomarine sediment flux, yields, and potential denudation rates (Trusel and others, 2008). Therefore, these data have been extrapolated at the fjord floor basin edges to increase their utility for sediment volume measurements.

Due to often poor between-track spatial resolution associated with the singlebeam collection methods in the NOS data, the historical bathymetric data points were manually modified to artificially increase fjord basin-edge resolution. While geographic locations of the historical soundings are potentially highly accurate (Umbach, 1976), even minor errors in horizontal location over variable-relief bathymetry can lead to large errors in depth measurement. This potential problem is avoided by making measurements only over the very low relief and slope basin floor areas, where poor between-track data coverage is not critical. We assume that the flat fjord floor character has remained relatively constant and that the primary temporal change has been basin-floor aggradation. This assumption is supported by seismic profiles showing thick and continuously well stratified glaciomarine sediment horizons in the deep basins of Muir Inlet that onlap adjacent walls and bathymetric highs (Seramur and others, 1997; Cowan and others, 1999). We also assume that the bulk of sediment accumulation occurs in the fjord-floor basins, either through direct deposition from glaciomarine suspension settling or through redepositional events from slope failures, sediment gravity flows, and other mass-movement processes common to fjords (Powell and Molnia, 1989; Syvitski, 1989). Using these two assumptions we have slightly modified the 1972 data by extrapolating the nearest depth soundings to the edges of the fjord floor basins as defined in the 2004 multibeam data. These modified data were interpolated and gridded using the natural neighbor interpolation function within $\mathrm{ArcGIS}^{\mathrm{TM}}$. In effect, this method simply extends accurate historical basin floor data to its edges to create a relatively planar surface that mirrors the inferred basin-floor morphology.

The modified 1972 bathymetric grid was differenced with the 2004 multibeam bathymetry using IVS3D Fledermaus software over only the flat, fjord-floor areas. In general, basin-floor areas were delineated as having a slope of less than $5^{\circ}$. The resulting sediment-thickness grid from Fledermaus was loaded into ArcGIS, where it was divided by 32 years (1972 to 2004) to calculate an average annual sediment accumulation rate between elapsed surveys.

\section{Results and Discussion}

\section{Benthic Cover Component}

Results of the subclass level BCC mapping for Muir Inlet are shown on the maps in sheets 2 and 3. Coverage for the BCC substrate classification is summarized for the entire fjord (table 4). As expected, unconsolidated bottom types dominate the Muir Inlet seascape, owing to the very large glaciomarine sediment flux. The largest measured area of Muir Inlet was the mesobenthic depth zone (table 3), which includes the majority of the basin floors and explains the high proportion of unconsolidated bottom. Nearly 90 percent of Muir Inlet is covered by mud. The second most abundant characterized substrate in Muir Inlet is bedrock, which forms about 6 percent of mapped substrate. Mixed sediments, which are likely to be a mix of sand- and gravel-sized particles, account for 3.2 percent of the measured substrates. Boulder/rubble was characterized in 1.3 percent or nearly $1 \mathrm{~km}^{2}$ of Muir Inlet. The cobble/gravel subclass could only be confidently placed over an area of $0.29 \mathrm{~km}^{2}$.

Table 4. Substrate distribution for Muir Inlet.

\begin{tabular}{llll}
\hline \multicolumn{1}{c}{ CMECS class } & CMECS subclass & $\begin{array}{c}\text { Percentage of } \\
\text { total area }\end{array}$ & Area $\left(\mathrm{km}^{2}\right)$ \\
\hline Unconsolidated & mud & 88.7 & 64.6 \\
bottom & mixed sediments & 3.3 & 2.4 \\
& cobble/gravel & 0.4 & 0.3 \\
Rock bottom & boulder/rubble & 1.4 & 1.0 \\
& bedrock & 6.2 & 4.5 \\
\hline
\end{tabular}

The predominance of mud substrate is expected since both sediment core (Cowan and others, 1999) and the accumulation data reveal significant annual accumulations of glaciomarine mud sourced from the proximal glaciers. In winter, however, core data reveal that, as the glacial meltwater systems slow, there is a relative increase in coarse material entrained and rafted by icebergs and sea ice to create a gravelly mud (diamict) layer (Cowan and others, 1999; Jackolski and others, 2006). Formation of the winter diamict is spatially heterogeneous because of limited sea ice extent, and its occurrence will 
likely decrease because of the emergence of the glaciers from tidewater (Cowan and others, 1999). Therefore, while some spatiotemporal variability in fjord-floor mud substrate exists, it is increasingly limited.

The summary of substrates for each CMECS depth zone illustrates the types of benthic habitats available at different depths within Muir Inlet (table 5). The majority of rock bottom substrates are located in the circalittoral (offshore) depth zone, because the fjord walls are predominantly located within this depth zone. Likewise, the vast majority of the fjord-basin floors exist within the mesobenthic depth zone, which contains the greatest abundance of mud. The mixed sediments subclass is found at almost equal proportions in both circalittoral (offshore) and mesobenthic depth zones. This is expected, because the subclass was used to characterize areas of higher backscatter intensity (and therefore coarser particles) relating to side-input sources that often span the entire fjord walls down to the basin floor.

Table 5. Substrate distribution by depth zone for Muir Inlet.

\begin{tabular}{|c|c|c|c|c|c|c|c|c|}
\hline \multirow[b]{2}{*}{ CMECS subclass } & \multicolumn{2}{|c|}{$\begin{array}{l}\text { Deep infralittoral: } \\
5-30 \text { m water depth }\end{array}$} & \multicolumn{2}{|c|}{$\begin{array}{c}\text { Circalittoral: } \\
\text { 30-80 m water depth }\end{array}$} & \multicolumn{2}{|c|}{$\begin{array}{l}\text { Circalittoral (offshore): } \\
80-200 \mathrm{~m} \text { water depth }\end{array}$} & \multicolumn{2}{|c|}{$\begin{array}{c}\text { Mesobenthic: } \\
200-1,000 \text { m water depth }\end{array}$} \\
\hline & Percent & Area $\left(\mathrm{km}^{2}\right)$ & Percent & Area $\left(\mathrm{km}^{2}\right)$ & Percent & Area $\left(\mathrm{km}^{2}\right)$ & Percent & Area $\left(\mathrm{km}^{2}\right)$ \\
\hline Mud & 0.05 & 0.04 & 3.53 & 2.57 & 28.79 & 20.95 & 56.35 & 41.00 \\
\hline Mixed sediments & 0 & 0 & 0.11 & 0.08 & 1.94 & 1.41 & 1.26 & 0.91 \\
\hline Cobble/gravel & 0 & 0 & 0.03 & 0.02 & 0.34 & 0.25 & 0.03 & 0.02 \\
\hline Boulder/rubble & 0 & 0 & 0.01 & 0.01 & 0.56 & 0.41 & 0.79 & 0.57 \\
\hline Bedrock & 0.01 & 0.01 & 0.43 & 0.31 & 3.95 & 2.88 & 1.83 & 1.33 \\
\hline
\end{tabular}

\section{Geoform Component}

Muir Inlet lies within the continental margin megageoform and is also a fjord megageoform. For simplicity, we characterized GFC down to the mesogeoform scale (tens of meters to kilometers in size). Additionally, the resolution of our data was a limiting factor in GFC characterization. The primary mesogeoforms characterized within Muir Inlet are fjord wall, floor, delta, and moraine. The high relative proportion of walls and floors is expected and is characteristic of glacial fjord morphology. Numerous deltas exist along the fjord walls that are both fluvial and glaciofluvial in origin; most are at least partially fed by glacial meltwater.

A large area at the fjord mouth is characterized as moraine using the CMECS terminology (sheet 4). This is an area of spatially concentrated and complex submarine glacial landforms, comprised of morainal banks, grounding-line fans, and preserved subglacial meltwater conduits (figs. 1,2, sheet 1). These landforms mark a period of slow retreat and quasi-stability of Muir Glacier between 1860 and 1899, when an abundant glacial-debris flux and terminus fluctuations resulted in their formation (Seramur and others, 1997; Trusel, 2009). Morainal banks are defined as elongate submarine sediment ridges formed in contact with a tidewater glacier at its grounding line and are composed of outwash, till (glacial diamict), and melt-out debris (Powell, 1981). Push morainal banks dominate the fjord mouth seascape, constructed by ice push or thrusting that commonly occurs during winter (Powell, 1981; Boulton, 1986). Several of these landforms are correlated to specific years between 1880 and 1899 (Seramur and others, 1997). Grounding-line fans are subaqueous, fan-shaped depocenters that mark the position of englacial and subglacial meltwater effluents (Powell, 1991). Their presence in this area indicates periods of quasi-stability, when glacial retreat slowed sufficiently for their construction.

Farther up the fjord, four prominent transverse ridges are characterized within Muir Inlet and labeled as "moraines" using the CMECS terminology (sheet 4). These bathymetric highs are inferred to be morainal banks composed primarily of coarse, ice-contact material deposited during the retreat of Muir Glacier. Terminus positions in 1911-1913, 1926-1931, 19461948, and 1958-1960 correlate to these morainal banks from south to north, respectively (Trusel, 2009). Seismic data reveal acoustic transparency at depth, suggesting that some of these features are bedrock-cored and therefore sills; whereas, others appear to be composed of purely discontinuous, hummocky, and mounded reflections interpreted to be ice-contact material (Trusel, 2009). Backscatter data, however, reveal a similar reflectance as the basin floors, with only minor areas of higher backscatter in gullies and small channels along the sides of these ridges. Such features indicate transport of material from the morainal banks into adjacent basins. Therefore, while exposed coarse ice-contact material certainly exists on these morainal banks, we infer that they are mostly draped with a layer of mud, based on their relatively low surface backscatter. In the similar setting of Simpson Bay in Prince William Sound, morainal banks and bedrock outcrops are observed to be draped in a veneer of estuarine mud (Noll and others, 2008), lending support to our interpretations. 
The relation of GFC to depth zone and dominant cover type can yield information on potential benthic habitats simply through the mapping of submarine landforms. Here, the floor geoform, as well as mud, is associated with the mesobenthic depth zone (table 6,7). Similarly, the majority of the wall geoform is found in the circalittoral (offshore) zone (table 7) where there is a greater diversity of substrate types (table 5). While we have not analyzed the statistical associations between GFC, depth zone, and substrate, general relations are observed and may be useful in mapping potential habitats in areas where only bathymetric data are available.

Table 6. Major GFC distribution for Muir Inlet.

\begin{tabular}{llll}
\hline Megageoform & Mesogeoform & $\begin{array}{c}\text { Percentage of total } \\
\text { area }\end{array}$ & Area $\left(\mathrm{km}^{2}\right)$ \\
\hline \multirow{4}{*}{ Fjord } & Delta & 5.8 & 4.6 \\
& Floor & 38.7 & 30.7 \\
& Moraine & 15.5 & 12.3 \\
& Wall & 40.0 & 31.7 \\
\hline
\end{tabular}

Table 7. Major GFC distribution by depth zone for Muir Inlet.

\begin{tabular}{lllllllll}
\hline & \multicolumn{2}{c}{$\begin{array}{c}\text { Deep Infralittoral: } \\
\text { 5-30 } \text { water depth }\end{array}$} & \multicolumn{2}{c}{$\begin{array}{c}\text { Circalittoral: } \\
\mathbf{3 0 - 8 0} \mathbf{m} \text { water depth }\end{array}$} & \multicolumn{2}{c}{$\begin{array}{c}\text { Circalittoral (offshore): } \\
\mathbf{8 0 - 2 0 0} \mathbf{m} \text { water depth }\end{array}$} & \multicolumn{2}{c}{$\begin{array}{c}\text { Mesobenthic: } \\
\text { 200-1000 } \mathbf{m} \text { water depth }\end{array}$} \\
\cline { 2 - 9 } CMECS subclass & Percent & Area $\left(\mathbf{k m}^{2}\right)$ & Percent & Area $\left(\mathbf{k m}^{2}\right)$ & Percent & Area $\left(\mathbf{k m}^{2}\right)$ & Percent & Area $\left(\mathbf{k m}^{2}\right)$ \\
\hline Delta & 0 & 0 & 0.37 & 0.29 & 3.68 & 2.92 & 1.80 & 1.43 \\
Floor & 0 & 0 & 0 & 0 & 0.69 & 0.55 & 38.0 & 30.13 \\
Moraine & 0 & 0 & 1.38 & 1.10 & 10.20 & 8.08 & 3.93 & 3.11 \\
Wall & 0.05 & 0.04 & 2.67 & 2.11 & 22.89 & 18.15 & 14.36 & 11.39 \\
\hline
\end{tabular}

The GFC is particularly useful in Muir Inlet for assessing areas of potential change. Large and rapid remobilization of sedimentary landforms has been observed in Glacier Bay (Hunter, 1994). Further, Glacier Bay is located in a seismically active region, because of its proximity to the Queen Charlotte-Fairwater Fault. In the event of a significant earthquake, the potential is high for catastrophic slope failures from fjord walls. Deltaic complexes are particularly susceptible to failure, because they are unconsolidated and rest on very steep bedrock. Such a failure would result in widespread sediment redistribution into the deep basin areas, burying any marine life in its proximity. Activation of submarine landslides by wave activity is unlikely, however, as waves in the fjord are limited by fetch. Conversely, there is the potential for the generation of wave activity generated by submarine landslides, although the magnitude and severity of these events is unknown.

\section{Water Column Component}

As with the BCC and GFC, the WCC is classified within the estuarine system. Benthic depth zones associated with oceanographic stations in Muir Inlet are classified as circalittoral offshore $(80-200 \mathrm{~m})$ and mesobenthic $(200-1,000 \mathrm{~m})$. The upper water column within Muir Inlet (above pycnocline) is always in the epipelagic water column depth zone ( $>0-200 \mathrm{~m})$, while the lower water-column varies between epipelagic and mesopelagic (200-1,000 m).

Despite the large spatial heterogeneity in tidal range within Glacier Bay (Hill, 2007), all stations in Glacier Bay, including Muir Inlet, were classified by CMECS as moderate tide range $(1-5 \mathrm{~m})$. Similarly, although there is large spatial heterogeneity in tidal velocity throughout Glacier Bay, including regions of extreme tidal currents (Hill, 2007; Hill and others, 2009), the use of averages within the CMECS system defined energy intensity within the upper water column at all stations as low energy (very weak currents; 0-2 knots). In shallower areas, such as station 15 (see fig. 6), bottom-layer energy intensity was also classified as low energy, while the bottom layers in deeper areas were classified as no energy (no detectable waves or current motion). For all stations in Muir Inlet except station 15, the upper layer energy type is classified as current (due to freshwater discharge and down-bay flow), while the bottom water column energy type is considered to be tide. Station 15 is more mixed and is influenced by tidal energy in both the upper and lower water layers. Energy direction in the upper water layers of Muir Inlet, as well as the rest of Glacier Bay, is considered horizontal. 
Upper- and lower-water-column temperatures in Muir Inlet were classified as cold $\left(0-10^{\circ} \mathrm{C}\right)$. Across all Muir Inlet stations, bottom waters were classified as euhaline (30-40 psu). Upper-water layers within Muir Inlet were mostly classified as mesohaline (5-18 psu), whereas the most seaward of the stations within Muir Inlet (station 15) was classified as polyhaline (18-30 psu). The averaging of salinity to obtain a single classification measurement removed the large seasonal variation in salinity patterns in Muir Inlet (Etherington and others, 2007b). For all stations in Muir Inlet except station 15, the primary water source for the upper water layers is watershed due to the influence of freshwater discharge from glacier, snow, and groundwater sources, while the bottom layers are primarily influenced by local estuary exchange (tidal exchange that is primarily estuarine water). For station 15 , the primary water source for both the upper and bottom water layers is local estuary exchange due to the more seaward location, shallower depth, and resultant higher mixing.

Using euphotic depth calculations (from photosynthetically available radiation data) instead of Secchi disk depth (which was specified by CMECS; Madden and others, 2008), turbidity levels within the upper water column within Muir Inlet were considered clear (euphotic depth of 5-20 m). However, the averaging of turbidity values does not capture the seasonally high turbidity in the summer months that results from extremely high sedimentation (Etherington and others, 2007b). Turbidity type was classified as mineral particulates at all stations except station 15, where turbidity was attributed to mineral particulates and chlorophyll, resulting in a classification of mixed. All stations within Muir Inlet were assigned a turbidity provenance of terrigenous origin. The photic properties of the bottom water column was aphotic for all stations, while the upper water column was defined as seasonally photic (varied between photic and aphotic) for all Muir Inlet stations except station 15, which was defined as photic throughout the year.

Macrohydroforms and mesohydroforms, as defined by CMECS, were not identified for Glacier Bay. The only identifiable CMECS lifeform was the phytoplankton maximum layer, which was assigned to the upper-water layer for all oceanographic stations. Trophic status, (defined as general categorization of the abundance of dissolved inorganic macronutrients (DIN) and dissolved inorganic phosphorus (DIP), and the level of primary productivity of a unit (Madden and others, 2008) is considered oligotrophic $(<5 \mu \mathrm{g} / \mathrm{L}$ chlorophyll $a)$ for both upper and lower water layers at all stations within Glacier Bay when averages are calculated over the whole year. No water column biotopes were identified.

Despite the highly variable nature of the water-column environment, particularly within an estuarine fjord system, the CMECS system provides only one opportunity to incorporate temporal variability (for all classes and attributes combined) into the classification of the water column. For all of Glacier Bay, the upper water column was classified with a temporal persistence value of variable (varies regularly) while the persistence of the bottom water layers was considered permanent (stable). It was not possible to identify multiple sources of variation (seasonal plus stochastic), so the dominant source of temporal change (seasonal) was defined.

Using the CMECS classification system, the water-column properties that illustrated the greatest amount of spatial variation in Glacier Bay, horizontally (among stations) and (or) vertically (between the upper and lower water layers), include benthic depth, salinity, energy source, and primary water source (fig. 7). Upper water layers demonstrate greater complexity than the bottom water layers and include a greater number of unique combinations of classes (habitat units). There were only two bottom water layer habitat units in Muir Inlet that vary only in benthic depth zone, with stations 15 and 20 exhibiting shallower depths than the rest of Muir Inlet (fig. 7A). Within Muir Inlet, there were three different habitat units of the upper water layer that varied by benthic depth, salinity, energy source, and primary water source (fig. 7B). The majority of the upper water column within Muir Inlet is composed of mesohaline waters that are mainly influenced by watershed sources and current energy within mesobenthic depths. Upper water layers of station 20 differ from the main-stem waters of Muir Inlet only in the benthic depth zone (circalittoral offshore). The upper water column habitats of station 15 differ from the other Muir Inlet stations more substantially, with different classes of benthic depth, salinity, energy source, and primary water source that reflect its more seaward location and shallower depth.

\section{Sediment Accumulation}

Average annual sediment accumulation rates for the period 1972 to 2004 are shown in figure 8. Accumulation measurements are limited in their northern extent because of the more advanced position of Muir Glacier in 1972. However, sediment accumulation proximal to the modern Muir Glacier terminus is expected to be similar to that near its 1972 grounding line, as well as to the rates proximal to Riggs Glacier (minimum $\sim 1 \mathrm{~m} / \mathrm{yr}$ ). This inference is supported by recent ${ }^{210} \mathrm{~Pb}$-derived sediment accumulation rates of $0.82 \mathrm{~m} / \mathrm{yr}$ measured about $2 \mathrm{~km}$ from the modern Muir Glacier delta (Cowan and others, 1999). Our results include (1) 20 years of glaciomarine sediment flux from Muir Glacier prior to its separation from the fjord by an ice contact delta in 1992 and (2) the pronounced ice-contact accumulation rates near the 1972 Muir Glacier grounding line. Recent rates measured near the 1972 terminus position indicate that modern sediment flux at this location has decreased to about 0.2 $\mathrm{m} / \mathrm{yr}$ (Cowan and others, 1999). According to power and exponential functions (Cowan and Powell, 1991; Trusel and others, 2008), this recent decreased flux, when compared to the longer-term average, is expected as sediment accumulation rates decrease rapidly with distance from glacier termini. Accumulations are on the order of a few centimeters a year towards the fjord mouth. Some basin-floor areas within Muir Inlet have no accumulation or even slight erosion (fig. 8: 0 m/yr). Lacking 


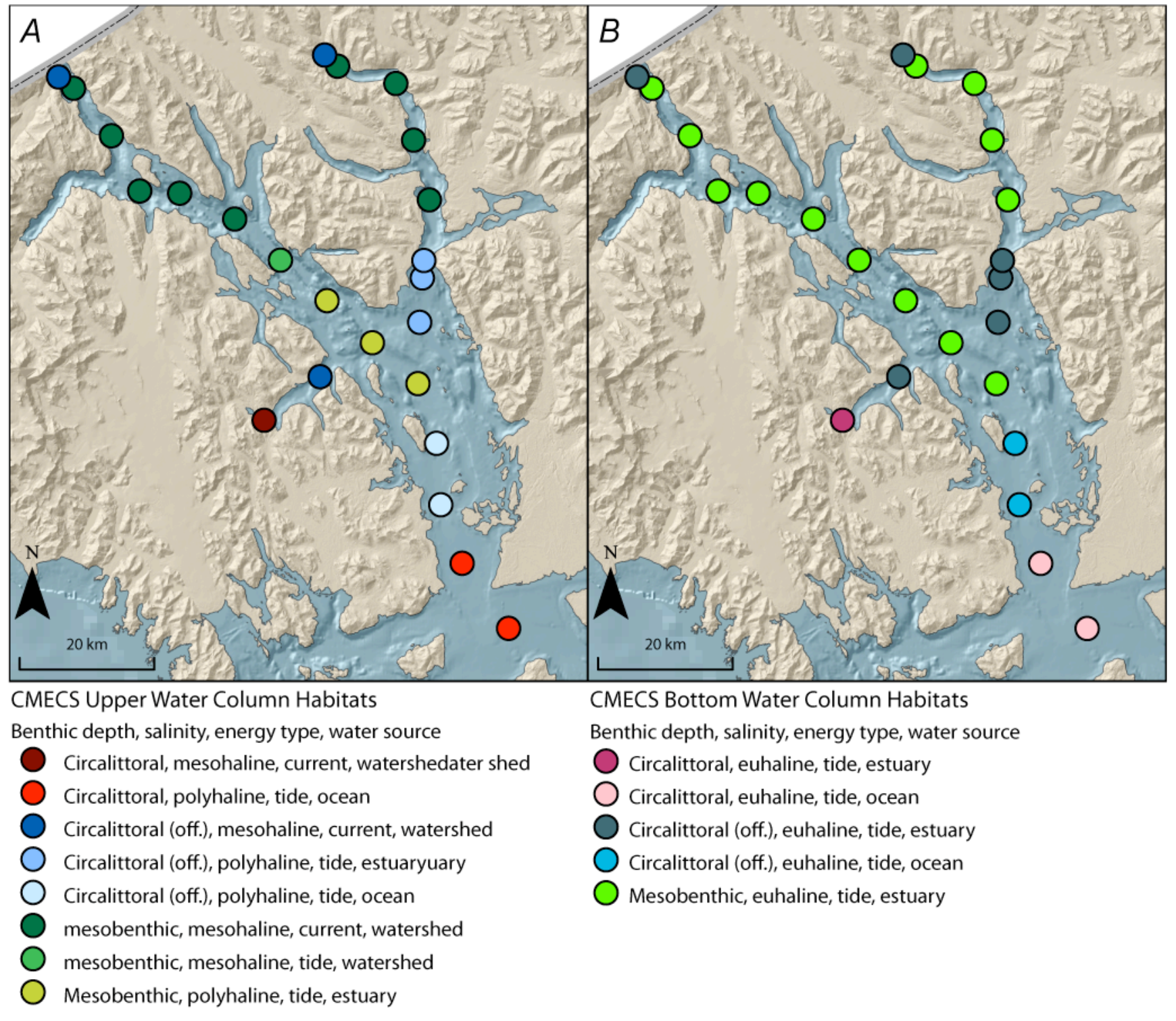

Figure 7. Maps showing $(A)$ upper and $(B)$ bottom water column CMECS habitats in Glacier Bay area.

evidence of strong currents, such areas are thought to be beyond the resolution of our data and are inferred to receive a similar low debris flux as the surrounding benthic environment.

Muir Inlet can be divided into two modern sedimentation regimes: a glacial sedimentation regime in the upper icecontact basin and a marine paraglacial sedimentation regime that exists for all basins south of Riggs Glacier. Measured rates in the upper basins average $0.5 \mathrm{~m} / \mathrm{yr}$, whereas in the lower basins sediment accumulation rates are far less but still sufficient to drape the seascape in glaciomarine mud. In effect, these accumulation rates split the fjord into two primary physical benthic environments. Upper Muir Inlet receives significant sediment flux, creating a higher likelihood of sediment gravity flows from unconsolidated sediments reaching critical angles along the fjord walls. Terrestrially sourced rock falls are also more prevalent in upper Muir Inlet, owing to the steep relief of the fjord walls and recent glacial retreat. Conversely, lower Muir Inlet is inferred to be a more static benthic environment with low sedimentation rates, approaching $0 \mathrm{~m} / \mathrm{yr}$, and therefore it has a lower potential for unconsolidated slope failures. With less vertical relief along the shores, there is also a lower potential for rock falls into the fjord. However, evidence of previous mass movements is inferred from bathymetry (sheet 1: fig. 3), although there is no temporal record for such events.

Sediment accumulation decay down-fjord is not only a function of distance from the glacial termini but is also influenced by submarine landforms. Sediment accumulation significantly decreases south of the northernmost morainal bank 


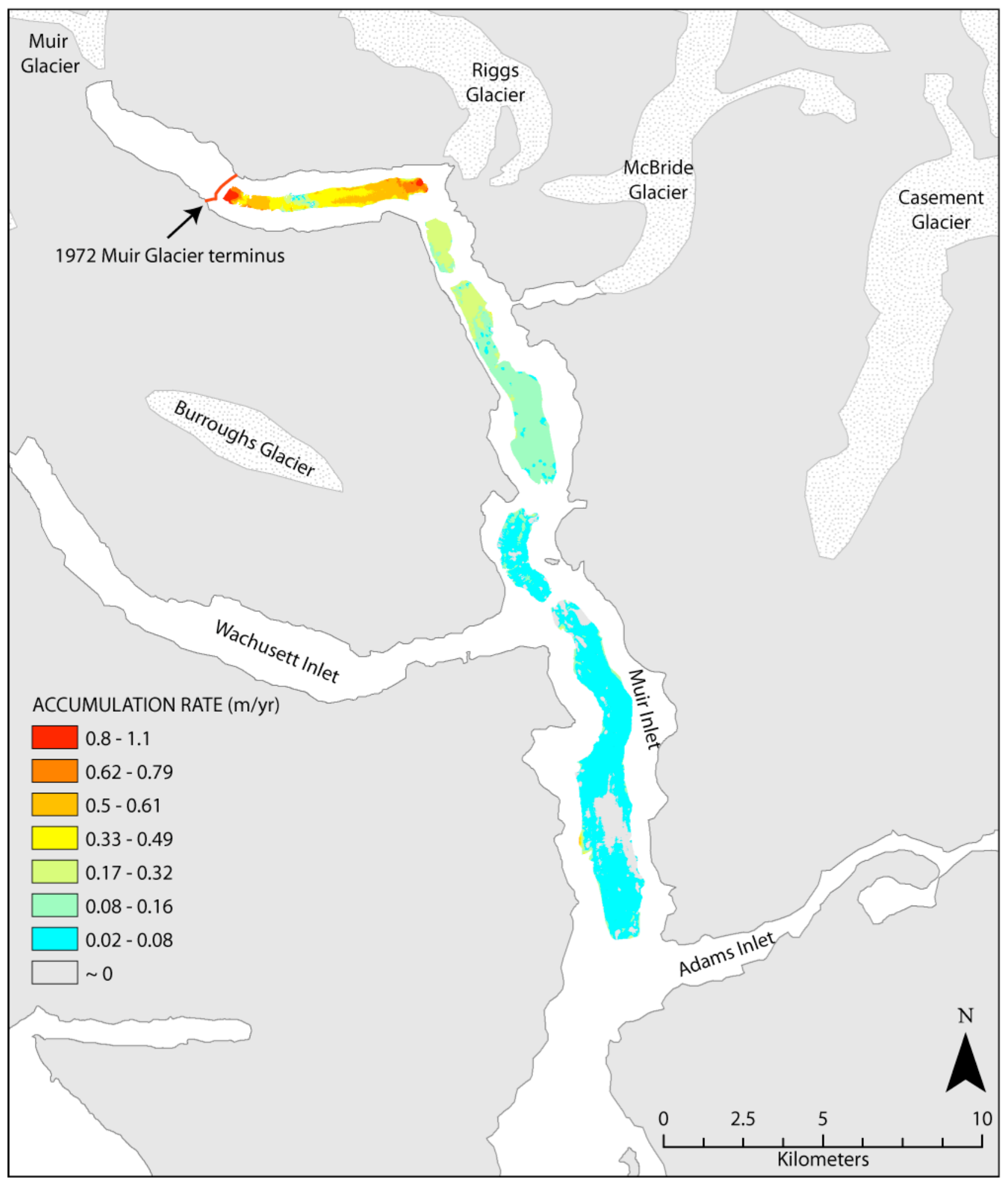

Figure 8. Map showing average annual sediment accumulation rates for $1972-2004$.

near Riggs Glacier (sheet 4: moraine mesogeoform). This characteristic is attributed to significant flocculation of clay- and siltsized particles and the bathymetric high inhibiting sediment transport. Currents and water-mass circulation associated with the high glacial meltwater runoff likely contribute to the observed sediment accumulation patterns. Similarly, there is no significant local signature observed within Muir Inlet of recent sediment accumulation sourced from McBride Glacier. This is attributed to 
the large ice-contact landforms at the entrance to McBride inlet that act to constrain the bulk of sediment flux from McBride Glacier, which is the prime sediment producer in the mid-fjord area today.

The majority of sediment accumulation occurring in the most proximal basin has ramifications for local benthic life, because of the pronounced sediment flux, but also for glacier dynamics. Grounding-line deposits act as a second-order control on the stability of glacier termini, and significant buildup at a glacier terminus can facilitate readvance (Powell, 1991; Fischer and Powell, 1998). McBride inlet receives sediment accumulation as high as $13 \mathrm{~m} / \mathrm{yr}$ or $1 \times 10^{6} \mathrm{~m}^{3} / \mathrm{yr}$ (Cowan and Powell, 1991). With the bulk of this sediment from McBride Glacier constrained to McBride inlet, it is conceivable that the inlet could aggrade to sea level if the terminus position remains relatively stable or retreats slowly. In this scenario, glacial advance would be facilitated if the glacier-mass balance were to become positive. Similarly, when the accommodation space within McBride inlet is exhausted, meltwater and debris will likely be transported directly into Muir Inlet via a braided stream network. Relocation of this point-source depocenter may affect local biota, including those species associated with one of the most extensive rock bottom habitats in Muir Inlet (sheet 3).

\section{Benthic Habitats}

Previous research has demonstrated classes of three bottom types most important to benthic organisms: soft-flat bottom, mixed bottom including coarse sediment and low-relief rock with low to moderate rugosity, and rugose-hard bottom (Greene and others, 2007; Cochrane, 2008). Muir Inlet has all of these types of habitat, with the greatest abundance being softflat bottom. In Glacier Bay, species associated with soft-flat bottom habitats include gastropod, algae, flatfish, Tanner crab, shrimp, sea pen, and other crustaceans (Etherington and others, 2007a). In the bay proper, soft corals and sponge are the only species found associated with boulder substrate (Etherington and others, 2007a). This is likely similar for Muir Inlet, because red tree corals (Primnoa pacifica) were found associated with bedrock between 9 and $35 \mathrm{~m}$ depth and provide important habitat for rockfish, among other species (Stone and others, 2005). We expect that geological-biological associations found in central Glacier Bay are at least partially analogous in Muir Inlet. Given that soft, mud substrate is the most prevalent habitat in Muir Inlet, we expect that the species associated with a soft bottom in the bay proper are the most abundant types of species within Muir Inlet. However, while mud is the dominant substrate throughout the fjord, upper and lower Muir Inlet are potentially very different environments, because of the spatially and temporally heterogeneous influence of glaciation and its associated effects on fjord hydrologic and oceanographic conditions. Therefore, we expect variations in the distribution of species accordingly.

The distribution of Tanner crab (Chionecetes bairdi), a mud-associated species, is a potential example of the existence of the two contrasting environments. Systematic sampling shows that Tanner crabs are found throughout Muir Inlet but are generally most abundant near the mouth and are sparse in the ice-contact basins at the head of the fjord (Mondragon and others, 2007a; Nielsen and others, 2007). Juvenile females were very dense in Wachusett Inlet, which is hypothesized to represent a suitable habitat for juveniles as opposed to adults, because of the generally lower biomass and food resources associated with glacial proximity (Nielsen and others, 2007). Relative to Muir Inlet, however, Wachusett Inlet receives a much lower glacial debris flux (Molnia and others, 1984). Indeed, upper Muir Inlet is likely a much harsher environment because of the extreme glacial influence and associated characteristics. The higher sediment flux may explain why juvenile Tanner crabs were not abundant in the similar soft-bottom habitat of upper Muir Inlet near glaciers. Depth may also play a role in the scarcity of juvenile Tanner crabs in upper Muir Inlet. The juvenile crabs were most abundant in the deepest portion of Wachusett Inlet ( $\sim 190 \mathrm{mbsl})$, however upper Muir Inlet is deeper ( $\sim 260 \mathrm{mbsl})$. With continued rapid aggradation of sediment, depths in these basins will likely decrease, depending on the magnitude of sediment flux and the interplay between isostatic uplift and sea level rise. This may expand the suitable habitat for these crabs if aggradation is later coupled with further retreat of the glacier termini and an associated decrease in sedimentation rates.

Muir Inlet has both shallow and deep-water benthic habitats. However, unlike Glacier Bay proper where large contrasts in the depth and current velocity define habitats (Etherington and others, 2007a), current velocities are relatively low for most of Muir Inlet (Etherington and others, 2007b; Hill, 2007). Currents are highest over the Muir Inlet entrance sill and at the mouth of Adams Inlet, however, they are much lower than those found in lower Glacier Bay (Etherington and others, 2007b). Therefore, while substrate and current exposure are the dominant factors controlling species distribution in the bay proper (Etherington and others, 2007a), currents are not as likely to play as large of a role in Muir Inlet. We expect substrate type and glacial proximity to be the most important habitat variables in Muir Inlet, although ground-truth is necessary to fully evaluate this hypothesis. 


\section{Discussion of the use of CMECS in Muir Inlet}

\section{Comments on CMECS}

Muir Inlet is a good test of CMECS because of the large temporal and physical variability of the environment at many periods and scales.

Overall, Glacier Bay had a comprehensive (both temporal and spatial) data set of attributes to test the application of CMECS as opposed to Columbia River estuary testing by Keefer and others (2008). Despite the comprehensive data set available for Glacier Bay, classifying many of the attributes was very difficult. This raises the question: what happens in areas that do not have very good or comprehensive attribute availability?

In Muir Inlet, CMECS is potentially very helpful for research applications in explaining spatio-temporal variability in invertebrate populations, could help identify and locate resources (geologic, biotic) that are present, and could be used to map out no-fishing zones (crab fisheries).

Using three separate components, separate layers, and different databases is acceptable. But is it practical in terms of quickly integrated access and analysis? The specifics of the database structure need to be better established to facilitate GIS analysis. The BCC is hierarchical (each attribute is nested in a higher level); the water column component is not hierarchical, and attributes are independent of one another; the GFC is not hierarchical and attributes are independent of one another (however, they do progress from large to small scales). Therefore, the three components are designed differently. Does this cause any database or GIS problems?

A CMECS database should include a time stamp and a mechanism for updates. Within CMECS, data are entered as an inventory; however, one goal of mapping is to identify temporal change. Within CMECS, is there a mechanism in the database that allows data to be updated or added temporally?

A CMECS map would need a companion document to help interpret information created with classification. What does a combination of classes mean ecologically? The biotope class does not fully describe unique ecosystems present in a mapped area. A given area might function similarly to another though it has different values for several attributes. An accompanying document may say areas are sensitive because they have soft corals, or a habitat type is tough to impact (resiliency, risk) and so forth. Is this part of CMECS or would it be better to make it part of a report that includes a CMECS inventory of attributes?

For sites that do not have abundant data, one should not be able to classify down to the finest degree. There should be rules about the type and resolution of data required at each resolution of detail.

Some of the problems with CMECS II identified in Keefer and others (2008) were retained in Version III (Madden and others, 2008). Keefer and others (2008) suggest that the CMECS could be improved by refining classification thresholds to better reflect ecological processes, by direct integration of temporal variability, and by more explicitly linking physical and biological processes with habitat patterns. Specific examples in the Keefer and others (2008) text follow:

"A single physical descriptor—-temporal persistence—was largely qualitative, which may at times be inadequate in highly dynamic estuarine systems like the CRE." (p. 102)

"CMECS lacks a suitable framework to capture and classify this type of predictable variability" (p. 102)

"Temporal variability should be more fully integrated into CMECS, perhaps as an additional category, nested within each hierarchical level" (p. 103)

"We believe energy intensity should perhaps be further classified. Although our study sites had significantly different benthic habitats, apparently as a function of energy inputs, all but one were classified as 'low energy' using the CMECS intensity scale, suggesting that this scale was too coarse for differentiating estuarine habitats that structure in response to subtle but critical energy differences." (p. 103)

\section{Comments on the Benthic Cover Component}

Overall, there is concern regarding the choice of abiotic versus biotic cover type at a very high level within the CMECS because it drives all subsequent classifications. Why have the split? One should be able to capture both abiotic and 
biotic components rather than one or the other. If cover is either biotic or abiotic, one is not able to assess the relation between dominant biological community (deep reef, coral garden, mussel beds) and substrate. Why lose the abiotic information if the biotic cover type is chosen? This approach inhibits the ability to associate abiotic cover to benthic and demersal organisms, an important process in defining preferred benthic habitats.

If there is no information to determine either abiotic or biotic cover, there should be a field or variable to state this. As currently defined, if a substrate has less than or greater than 10 percent cover, it is classified either abiotic or biotic, respectively. As an example, a substrate may have a 25 percent vegetation or epifaunal cover over an abiotic cover of 75 percent. Biotic cover may be greater than 10 percent, but it may not be dominant (as the cover type choice is defined). Why is 10 percent considered the dividing point? Rather than having a cutoff value (classifier) for biotic cover (at 10 percent), include a modifier of percent cover.

There are some issues and need for guidelines for implementation of CMECS in GIS (can a polygon have both biotic and abiotic elements?). If biotic cover is observed at a point sample, how far from that point can you extrapolate into a polygon, or should CMECS be restricted to point data without inferences. How do you make a biotic map? Is the final CMECS product a biotic data point shapefile layer over continuous abiotic polygons?

The definition of unconsolidated cover was vague. There is unconsolidated material that is hard but not rock. Specific to regions influenced by glaciation, consolidated glacigenic sediments (diamicts/till) are likely to exist. Within CMECS currently, it is unclear how this should be classified (is it to be classified in the rock bottom class?). We feel there are not enough substrate classes to distinguish important ecosystems. We suggest adding three substrate classes-rock, coarse sediment, and fine sediment - because these have been found to be the most important to benthic habitats (Greene and others, 2007; Cochrane, 2008).

If the importance of biotic cover drives the benthic cover component classification, collecting biotic data would be a top priority for any agency applying the CMECS system; having an unknown status high in the hierarchy is problematic. Collection of biotic data over wide spatial scales is an immense task, especially in Muir Inlet. If remote sensing provides only an abiotic map, is it a CMECS map?

Habitat maps should be useful, for example, for defining species composition. What biologic information should a manager expect from depth, substrate type, and so on? CMECS may meet these criteria in biotic cover or biotope, but its utility is uncertain based on the choice of biotic or abiotic cover. And those elements of CMECS do not generate species composition. Biotope seems to be specific to organisms attached to substrate. Therefore, to some degree, classes should be more detailed.

Based on our understanding of biotope, benthic biotopes identified for Muir Inlet include Modiolus sp. mussel beds, deep coral/sponge mosaic, and Nereocystis sp. kelp beds.

\section{Comments on the Water Column Component}

The WCC was developed for all of Glacier Bay in this pilot study. The greatest challenge within the WCC is how to deal with temporal change. The one attribute of temporal persistence is not sufficient to capture patterns of temporal variability among multiple aspects of the system. For Glacier Bay, the average values of attributes across all seasons and all conditions (neap- and spring-tide conditions) were used, averaging a highly variable system. Averaging the data lost some of the most important sources of variability and made the system appear homogenous, despite known strong spatial gradients along the bay axis. Averaging caused all of Glacier Bay to have the same energy intensity (all low); there are extremes in energy levels throughout the bay that are not captured. When turbidity levels were averaged over the year (using photic depth instead of Secchi depth), the CMECS class defined glacially influenced areas of the park as "clear" (5-20-m Secchi depth). This class and description does not reflect the highly turbid conditions within the bay throughout much of the year (Glacier Bay has some of the highest suspended sediment concentrations in the world).

Possible solutions to the temporal aspect could be to map each of the seasons separately, given the very large seasonality in water-column properties (salinity, stratification, turbidity, light levels, chlorophyll $a$ ) that drive biological patterns. Modifiers would be helpful to refine the attributes (average was low, but highly variable). Capturing maximum values also would be important.

For the Glacier Bay pilot project water-column structure was used as a way to define vertical zones; horizontal attributes were defined for each of the vertical depth zones (upper water column layer, bottom water column layer). Water column depth zones did not capture important vertical variation in the water column (dynamic surface layers). Specific guidance on how to use vertical attributes (water column depth zones; water column structure) and how to integrate with horizontal attributes is needed. How are these attributes combined in a database?

Several of the main attributes of the WCC were not populated because it was unclear what was meant by the macroand meso-hydroforms. For example, how do you define an effluent, a small freshwater lens, or a convergence? What boundaries and scales should be used to define these mesohydroforms? Can one only choose one mesohydroform or can one define multiple mesohydroforms in the same space? 
The lifeforms attribute was not very useful because only the phytoplankton maximum layer is observed in Glacier Bay. The phytoplankton maximum layer was assigned to the upper water column, which was not very useful. No biotopes were defined within the water column. What else, in addition to the example of Sargassum mats that is given, would be considered a biotope (as it is currently defined).

\section{Comments on the GFC Component}

More than one kind (mega/mesogeoform) of fjord is desirable (Glacier Bay is a temperate glacial fjord). It may be useful for the classification, if rules define how fjords differ by using data inputs to help define how the fjords are different. Alternatively, the WCC could be used to define the type of fjord, rather than explicitly having a category for fjord type, given that there are only temperate fjords in the U.S.

Spatial scales and nesting hierarchy need to be better defined. Glacier Bay is a fjord megageoform within the continental margin megageoform, based on the CMECS GFC scale definitions. Defining morphologic features based on scales that overlap is problematic and subjective. For example, megageoform is anything "kilometers to 10s of kilometers and larger". Mesogeoform is anything "10s of meters to kilometers" (Madden and others, 2008). Certain morphologic features may be classified as either or both because there is overlap between the scales. Setting-specific boundaries between the scales would make this process less subjective. Considering the goal of a nationwide classification standard wherein GFC and their associated habitats may be compared, defining specific scale boundaries would be useful.

The documentation is not clear when talking of scale of geoform. Are geoforms based on a linear scale or area? If it is a linear scale, should the longest axis be used? For example, a very narrow but long channel may not cover much area and may fit into two geoform classes, depending on which axis is measured if it is defined linearly. If geoforms are defined by areal extent, which may be the best option, the scales should be redefined. For example, mesogeoform is defined as " 10 s of meterskilometers" (Madden and others, 2008). If this is an area, it equates to $1.0 \times 10^{-5} \mathrm{~km}^{2}$ to $1+\mathrm{km}^{2}$ and nearly every morphologic feature would fit into the mesogeoform category.

GFC need to be expanded to include sills, which are common in glacial fjords. While the term "shoal" is effective, sill would be more accurate in Glacier Bay. If adding new geoforms is acceptable, CMECS should explicitly state this in the framework. The GFC ice feature needs to be defined. The term could mean several or all things in a glacial fjord.

Bathymetric Position Index (BPI) is not captured in the GFC, although it is considered very useful. BPI should be calculated at multiple scales (small to large), because the same value may be defining a small rise or an extensive bank, depending upon scale. Rules would be needed to set the radius. It would be useful to define the scales that are relevant; scales of fish species may be important but different from other faunal community members. BPI could also be included as a modifier attribute.

\section{Comments on Modifiers and Attributes}

Substrate is not included as a modifier attribute; therefore, if a biotic subclass is chosen, there is no place for abiotic substrate information. Ground-truth methods used by USGS and NOAA include observations of primary substrate ( $>50 \%)$ and secondary substrate $(>20 \%)$.

It would be useful to add an attribute for water-column stratification. Stratification is both important to species within the water column and for benthic organisms at shallow depth in glaciated fjords and estuarine environments.

CMECS calls for Secchi depth as a measurement of turbidity. Secchi disks are not often used for oceanographic measurements, and these values should be changed to reflect the range of optical backscatter and calculated concentrations of sediment within the water column. Alternatively, euphotic depth levels could be used (for example, where surface light levels become minimal).

For several of the attributes, the classes need to be refined. For example, Glacier Bay fell into the moderate category for tide range $(1-5 \mathrm{~m})$. The bay has one of the largest tidal fluxes in the world (few places would fit the large tide range class, except the Bay of Fundy). This would suggest that the classes need to be further refined or a series of subclasses should be added to the classification scheme. Also, the classes within energy intensity need to be refined and expanded.

To reiterate highlights in Keefer and others (2008), we believe energy intensity should be further classified. Although our study sites had significantly different benthic habitats (cobble/sand versus mud), apparently as a function of energy levels, they were similarly classified as low energy using the CMECS intensity scale, suggesting that this scale was too coarse for differentiating estuarine habitats. Similarly, the energy intensity classes were not able to differentiate between very different upper water column energy regimes within the bay. Part of this problem could be due to averaging values to assign only one class for the attribute.

Sedimentation rate would be a useful addition to either the BCC, WCC, or as a modifier. High clastic sediment fluxes to the benthos in glaciated fjords is an important physical control on the distribution of biota (Carney and others, 1999; 
Wlodarska-Kowalczuk and Pearson, 2004). Sediment flux is potentially a dominant and limiting factor that defines benthic habitats for some organisms, which is relevant in fjords and other areas with high sediment fluxes.

\section{Conclusions}

Seafloor substrates and morphology in Muir Inlet were mapped using a combination of data sources including multibeam bathymetry and backscatter data and knowledge of the glaciomarine environment. Substrate characterization, combined with information about depth, morphology, glacial influence, and current velocity provide the necessary variables to define potential benthic habitats in Muir Inlet. The Coastal and Marine Ecological Classification Standard (Madden and others, 2008) version III was used for the classification. Mud is the dominant substrate within Muir Inlet, covering nearly 90 percent of the seafloor. Bedrock was the next most abundant substrate, covering about 6 percent of the survey area. The remaining portion of Muir Inlet is covered by a mixture of coarser sediment and boulder/rubble. We expect organisms that were found associated with similar habitats in Glacier Bay proper are also abundant in Muir Inlet, with the largest benthic communities being those associated with mud substrate.

Upper Muir Inlet receives the bulk of sediment flux from Muir and Riggs Glaciers, while debris flux from McBride Glacier is mostly confined to McBride inlet. Because of the contrast in sediment accumulation rates between upper and lower Muir, the fjord can be characterized as two distinct regions. Upper Muir is more dynamic and has a higher likelihood of slope failures, whereas lower Muir is probably a more static benthic environment. Catastrophic failures of deltaic deposits are possible with significant seismic activity, influencing both proximal benthic life and potentially generating landslide-induced wave activity.

Glacial meltwater and debris flux affect the spatial distribution and variety of benthic fauna and flora in the arctic (Wlodarska-Kowalczuk and Pearson, 2004) and distribution and diversity of wall communities in Muir Inlet (Carney and others, 1999). However, the degree to which these variables act as physical controls in the deep basins within Muir Inlet is unknown. We postulate that the temperate glaciomarine environment, with some of the highest sediment fluxes recorded worldwide, may act as a limiting factor on the diversity, abundance, and distribution of these benthic communities, particularly in upper Muir Inlet where sediment flux is pronounced. Similarly, the potential exists for areas of intermediate disturbance levels along the fjord axis to support higher diversity and abundance. Further, seafloor video observations in Muir Inlet are necessary to evaluate these relations and are critical to fully understand the capacity of Muir Inlet as a marine reserve.

\section{Management Implications}

This publication presents the first substrate and high-resolution bathymetric maps for Muir Inlet, the east arm of Glacier Bay. Substrate, morphology, depth, water column, and glacial processes are all important factors in determining the distribution, abundance, and diversity of demersal and benthic marine life. Therefore, these maps and GIS products are important to scientists and managers to better understand the capacity of Muir Inlet to act as a marine reserve. These results serve as a baseline for the assessment of future environmental change, resulting from both the influences of proximal glaciation as well as dynamic fjord processes. Given stresses on the glacial estuary because of amplified high-latitude climate change and the commercial, recreational, and scientific importance of the Glacier Bay ecosystem, a full understanding of the modern system is fundamental for understanding its resources and developing the most appropriate management strategies.

\section{Acknowledgments}

Funding for this benthic habitat study was provided by the National Park Service. Geophysical data used in this analysis were collected with support from the National Science Foundation (NSF\# OCE 0242084 to Alan Mix, Chief Scientist, and NSF\# OCE 0351089 to Ross D. Powell). The WCC analysis by Lisa Etherington was done through cooperative habitat studies funded by NOAA Sanctuaries. Critical assessments by U.S. Geological Survey scientists were fundamental in shaping the final publication. The authors would like to thank Scott Gende for his work in convening and organizing the Muir Inlet benthic habitats meeting at which additional comments regarding the implementation of CMECS from Scott Gende, Brendan Moynahan, Lewis Sharman, and Craig Smith were obtained that were very helpful. Assistance from Nadine Golden with FGDC metadata procedures is greatly appreciated. This work was improved by thoughtful comments during review by Dr. Jeff Cross of the NPS and Dr. Eric Grossman of the USGS. This is a contribution of the Analytical Center for Climate and Environmental Change at Northern Illinois University.

\section{References Cited}

Boulton, G.S., 1986, Push-moraines and glacier-contact fans in marine and terrestrial environments: Sedimentology, v. 33, p. 677-698.

Cai, J., Powell, R.D., Cowan, E.A., and Carlson, P.R., 1997, Lithofacies and seismic reflection interpretations of temperate glaciomarine sedimentation in Tarr Inlet, Glacier Bay, Alaska: Marine Geology, v. 145, p. 5-37. 
Carlson, P.R., Hooge, P., Cochrane., G., Stevenson, A., Dartnell, P., and Lee, K., 2002, Multibeam bathymetry and selected perspective views of main part of Glacier Bay, Alaska: U.S. Geological Survey Open-File Report 02-391

(http://geopubs.wr.usgs.gov/open-file/of02-391).

Carney, D., Oliver, J.S., and Armstrong, C., 1999, Sedimentation and composition of wall communities in Alaskan fjords: Polar Biology, v. 22, p. 39-49.

Cochrane, G.R., 2008, Video-supervised classification of sonar data for mapping seafloor habitat, in Reynolds, J.R., and Greene, H.G., eds., Marine habitat mapping technology for Alaska: University of Alaska Fairbanks, Alaska Sea Grant College Program, p.185-194.

Cowan, E.A., and Powell, R.D., 1990, Suspended sediment transport and deposition of cyclically interlaminated sediment in a temperate glacial fjord, Alaska, U.S.A., in Dowdeswell, J.A., and Scourse, J.D., eds., Glaciomarine environments-Processes and sediments: Geological Society Special Publication 53, p. 75-89.

Cowan, E.A., and Powell, R.D., 1991, Ice-proximal sediment accumulation rates in a temperate glacial fjord, southeastern Alaska, in Anderson, J.B., and Ashley, G.M., eds., Glacial marine sedimentation; Paleoclimatic significance: Boulder, CO, Geological Society of America Special Paper 251, p. 61-73.

Cowan, E.A., and Powell, R.D., 2007, High frequency climate signals in fjord sediments of Glacier Bay National Park Alaska, in Piatt, J.F., and Gende, S.M., eds., Proceedings of the Fourth Glacier Bay Science Symposium, October 26-28, 2004: U.S. Geological Survey Scientific Investigations Report 2007-5047, p. 46-49.

Cowan, E.A., Seramur, K.C., Cai, J., and Powell, R.D., 1999, Cyclic sedimentation produced by fluctuations in meltwater discharge, tides, and marine productivity in an Alaskan fjord: Sedimentology, v. 46, p. 1109-1126.

Cowan, E.A., Seramur, K.C., Willems, B.A., Powell, R.D., Gulick, S.P.S., and Jaeger, J.M., 2008, Retreat sequences from the last glacial maximum and little ice age preserved in Muir Inlet, Glacier Bay National Park, southeastern Alaska: Geological Society of America Abstracts with Programs, v. 40, no. 6, p. 226.

Elverhøi, A., Hooke, R. LeB., and Solheim, A., 1998, Late Cenozoic erosion and sediment yield from the Svalbard-Barents Sea region-Implications for understanding erosion of glacierized basins: Quaternary Science Reviews, v. 17, p. 209-241.

Etherington, L., Cochrane, G., Harney, J., Taggart, J., Mondragon, J., Andrews, A., Madison, E., Chezar, H., and de La Bruere, J., 2007a, Glacier Bay seafloor habitat mapping and classification-First look at linkages with biological patterns, in Piatt, J.F., and Gende, S.M., eds., Proceedings of the fourth Glacier Bay science symposium, October 26-28, 2004: U.S. Geological Survey Scientific Investigations Report 2007-5047, p. 71-75.

Etherington, L.L., Hooge, P.N., Hooge, E.R., and Hill, D.F., 2007b, Oceanography of Glacier Bay, Alaska-Implications for biological patterns in a glacial fjord estuary: Estuaries and Coasts, v. 30, no. 6, p. 927-944.

Field, W.O., 1947, Glacier recession in Muir Inlet, Glacier Bay, Alaska: Geographical Review, v. 37, no. 3, p. 369-399.

Fischer, M.P., and Powell, R.D., 1998, A simple model for the influence of push-morainal banks on the calving and stability of glacial tidewater termini: Journal of Glaciology, v. 44, p. 31-41.

Fonseca, L., and Calder, B., 2005, Geocoder-An efficient backscatter map constructor: San Diego, CA, Proceedings of the U.S. Hydro 2005 Conference.

Goldwait, R.P., 1974, Rates of formation of glacial features in Glacier Bay, Alaska, in Coates, D.R., ed., Glacial geomorphology: Binghamton, SUNY, v. 5, p. 163-185.

Greene, H.G., Bizzaro, J.J., O’Connell, V.M., and Brylinsky, C.K., 2007, Construction of digital potential marine benthic habitat maps using a coded classification scheme and its application, in Todd, B.J., and Greene, H.G., Mapping the seafloor for habitat characterization: Geological Association of Canada Special Paper 47, p. 141-155.

Hall, D.K., Benson, C.S., and Field, W.O., 1995, Changes of glaciers in Glacier Bay, Alaska, using ground and satellite measurements: Physical Geography, v. 16, no. 1, p. 27-41.

Hallet, B., Hunter, L., and Bogen, J., 1996, Rates of erosion and sediment evacuation by glaciers-A review of field data and their implications: Global and Planetary Change, v. 12, p. 213-235.

Harney, J.N., Cochrane, G.R., Etherington, L.L., Dartnell, P., Golden, N.E., and Chezar, H.. 2007, Geologic characteristics of benthic habitats in Glacier Bay, Alaska, derived from geophysical data, videography, and sediment sampling, in Piatt, J.F., and Gende, S.M., eds., Proceedings of the Fourth Glacier Bay Science Symposium, October 26-28, 2004: U.S. Geological Survey Scientific Investigations Report 2007-5047, p. 37-41.

Hill, D. F., 2007, Tidal modeling of Glacier Bay, Alaska-Methodology, results, and application: State College, PA, Pennsylvania State University unpublished report, 139 p. (http://water.engr.psu.edu/hill/research/glba/default.stm).

Hill, D.F., Ciavola, S.J., Etherington, L., and Klaar, M.J., 2009, Estimation of freshwater runoff into Glacier Bay, Alaska, and incorporation into a tidal circulation model: Estuarine, Coastal, and Shelf Science, v. 82, p. 95-107 (doi: 10.1016/j.ecss.2008.12.019).

Hooge, P.N., and Hooge, E.R., 2002, Fjord oceanographic processes in Glacier Bay, Alaska: U.S. Geological Survey, Alaska Science Center, Anchorage, AK, unpublished report, $142 \mathrm{p}$.

(http://www.nps.gov/glba/naturescience/upload/Hooge_2002_OceanReport.pdf).

Hunter, L.E., 1994, Grounding-line systems and glacier mass balance of modern temperate glaciers and their effect on glacier stability: Northern Illinois University, DeKalb, IL, Unpublished Ph.D. dissertation. 
Hunter, L.E., Powell, R.D., and Lawson, D.E., 1996, Flux of debris transported by ice at three Alaskan tidewater glaciers: Journal of Glaciology, v. 42, p. 123-135.

Jackolski, C.L., Cowan, E.A., Jaeger, J.M., and Powell, R.D., 2006, High-resolution glacial discharge records from deep-water tidal rhythmites in an Alaskan fjord: Fall Meeting Supplement, Abstract PP51C-1155, Eos, Transactions of the American Geophysical Union, v. 87, no. 52.

Jenness, J., 2003, Raster surface areas - Surface area and ratios from elevation rasters electronic manual. Jenness Enterprises, ArcView Extensions (http://www.jennessnet.com/arcview/arcview_extensions.htm).

Jonman, R.H.G, terBraak, C.G.F., and Vantongeren, O.F.R., 1995, Data analysis in community and landscape ecology: Cambridge, Cambridge University Press.

Keefer, M.L., Peery, C.A., Wright, N., Daigle, W.R., Caudill, C.C., Clabough, T.S., Griffith, D.W., and Zacharias, M.A., 2008, Evaluating the NOAA Coastal and Marine Ecological Classification Standard in estuarine systems-A Columbia River Estuary case study: Estuarine, Coastal, and Shelf Science, v. 78, p. 89-106.

Larsen, C.F., Motyka, R.J., Echelmeyer, K.A., and Geissler, P.E., 2007, Glacier changes in southeast Alaska and northwest British Columbia and contribution to sea level rise: Journal of Geophysical Research, v. 112, p 1-11.

Larsen, C.F., Motyka, R.J., Freymueller, J.T., Echelmeyer, K.A., and Ivins, E.R., 2004, Rapid uplift of southern Alaska caused by recent ice loss: Geophysical Journal International, v. 158, p. 1118-1133.

Luthcke, S.B., Arendt, A.A., Rowlands, D.D., McCarthy, J.J., and Larsen, C.F., 2008, Recent glacier mass changes in the Gulf of Alaska region from GRACE mascon solutions: Journal of Glaciology, v. 54, no. 188, p. 767-777.

Madden, C.J., Goodin, K.L., Allee, R., Finkbeiner, M., and Bamford, D.E., 2008, Draft Coastal and Marine Ecological Classification Standard: National Oceanic and Atmospheric Administration (NOAA) and NatureServe, v. III, 77 p.

Madden, C.J., Goodin, K., Allee, R.J., Cicchetti, G., Moses, C., Finkbeiner, M., and Bamford, D., 2009, Draft Coastal and Marine Ecological Classification Standard: National Oceanic and Atmospheric Administration (NOAA) and NatureServe, v. III, 109 p. (download draft at http://www.csc.noaa.gov/benthic/cmecs/).

Meier, M.F., Dyurgerov, M.B., Rick, U.K., O’Neel, S., Pfeffer, T., Anderson, R.S., Anderson, S.P., and Glazovsky, A.F., 2007, Glaciers dominate eustatic sea-level rise in the $21^{\text {st }}$ century: Science, v. 317, no. 5841, p. 1064-1067.

Molnia, B.F., Atwood, T.J., Carlson, P.R., Post, A., and Vath, S.C., 1984, Map of marine geology of Upper Muir and Wachusett inlets, Glacier Bay, Alaska-Sediment distribution and thickness, bathymetry, and interpreted seismic profiles: U.S. Geological Survey Open-File Report 84-632, 3 sheets (http://www.dggs.dnr.state.ak.us/pubs/pubs?reqtype = citation\&ID=12138).

Mondragon, J., Etherington, L., Taggart, S.J., Hooge, P.N., 2007b, The distribution and abundance of Pacific Halibut in a recently deglaciated fjord-Implications for marine reserve design, in Piatt, J.F., and Gende, S.M., eds., Proceedings of the Fourth Glacier Bay Science Symposium, October 26-28, 2004: U.S. Geological Survey Scientific Investigations Report 2007-5047, p. 107-109.

Mondragon, J., Taggart, S.J., Andrews, A.G., Nielsen, J.K., de La Bruere, J., 2007a, Spatial distribution and relative abundance of Tanner and red king crab inside and outside of marine reserves in Glacier Bay, Alaska, in Piatt, J.F., and Gende, S.M., eds., Proceedings of the Fourth Glacier Bay Science Symposium, October 26-28, 2004: U.S. Geological Survey Scientific Investigations Report 2007-5047, p. 84-86.

Nielsen, J.K., Taggart, S.J., Shirley, T.C., and Mondragon, J., 2007, Spatial distribution of juvenile and adult female Tanner crabs (Chionoecetes bairdi) in a glacial fjord ecosystem-Implications for recruitment processes: ICES Journal of Marine Science, v. 64, p. 1772-1784.

NOAA, 1972a, Descriptive Report, Hydrographic Survey H09317, Upper Portion of Muir Inlet, Glacier Bay, Alaska: Norfolk, VA, National Oceanic and Atmospheric Administration (NOAA) National Ocean Service (http://surveys.ngdc.noaa.gov/mgg/NOS/DRs/H08001-H10000/H09317.pdf).

NOAA, 1972b, Descriptive Report, Hydrographic Survey H09318, Lower Portion of Muir Inlet and Adams Inlet, Glacier Bay, Alaska: Norfolk, VA, National Oceanic and Atmospheric Administration (NOAA) National Ocean Service (http://surveys.ngdc.noaa.gov/mgg/NOS/DRs/H08001-H10000/H09318.pdf).

Noll, C.J., Dellapenna, T.M., Gilkinson, A., and Davis, R.W., 2008, A high-resolution geophysical investigation of sediment distribution controlled by catchment size and tides in a multi-basin turbid outwash fjord-Simpson Bay, Prince William Sound, Alaska: Geo-Marine Letters (doi 10.1007/s00367-008-0120-8).

Piatt, J.F., and Gende, S.M., eds., 2007, Proceedings of the Fourth Glacier Bay Science Symposium: U.S. Geological Survey Scientific Investigations Report 2007-5047, 246 p.

Powell, R.D., 1981, A model for sedimentation by tidewater glaciers: Annals of Glaciology, v. 2, p. $129-134$.

Powell, R.D., 1984, Guide to glacial geology of Glacier Bay, southeastern Alaska-Glacial history, glacial sedimentology, glacial geomorphology, and glaciomarine sedimentation: Anchorage, Alaskan Geological Society, 85 p.

Powell, R.D., 1991, Grounding-line systems as second-order controls on fluctuations of tidewater termini of temperate glaciers - Glacial marine sedimentation, paleoclimatic significance: Geological Society of America Special Paper 261, p. 7594. 
Powell, R.D., and Molnia, B.F., 1989, Glaciomarine sedimentary processes, facies and morphology of the south-southeast Alaska shelf and fjords, in Powell, R.D., and Elverhøi, A., eds., Modern glaciomarine environments - Glacial and marine controls of modern lithofacies and biofacies: Marine Geology, v. 85, p. 359-390.

Seramur, K.C., Powell, R.D., and Carlson, P.R., 1997, Evaluation of conditions along the grounding line of temperate marine glaciers-An example from Muir Inlet, Glacier Bay, Alaska: Marine Geology, v. 140, p. 307-328.

Stone, R.P., Mondragon, J., and Andrews, A.G., 2005, Deepwater emergence of Red Tree Coral (Primnoa sp.) in Glacier Bay, Alaska: Miami, FL, Rosenstiel School of Marine and Atmospheric Science, Proceedings of the $3^{\text {rd }}$ International Symposium on Deep-Sea Corals Science and Management Programs and Abstract Book, p. 221.

Syvitski, J.P.M., 1989, On the deposition of sediment within glacier-influenced fjords-Oceanographic controls, in Powell, R.D., and Elverhøi, A., eds., Modern glaciomarine environments - Glacial and marine controls of modern lithofacies and biofacies: Marine Geology, v. 85, p. 301-329.

Trusel, L.D., 2009, Inferences into glaciomarine sediment yields, landforms, and environments from multibeam sonar records in Alaskan fjords: DeKalb, IL, Northern Illinois University, unpublished M.S. Thesis.

Trusel, L.D., Willems, B.A., Powell, R.D., and Mayer, L.A., 2008, Quantification of glaciomarine sediment yields using multibeam sonar in Alaskan fjords: Fall Meeting Suppl., Abstract C11B-0508, Eos, Transactions of the American Geophysical Union, v. 89, no. 53.

Trusel, L.D., Powell, R.D., Willems, B.A., and Mayer, L.A., 2009, Inferences into temperate fjord deglaciation-Evidence from glacial and paraglacial submarine landforms: Geological Society of America Abstracts with Programs, v. 41, no. 4.

Umbach, M.J., 1976, Hydrographic Manual (4th ed.): U.S. Department of Commerce, Coast and Geodetic Survey, 400 p. (http://www.thsoa.org/pdf/hm1976/hmall.pdf).

Wilson, J.C., and Overland, J.E., 1987, Meteorology, in Hood, D.W., and Zimmerman, S.T., eds., The Gulf of Alaska: U.S. Department of Commerce National Oceanic and Atmospheric Administration, p. 31-54.

Wlodarska-Kowalczuk, M., and Pearson, T.H., 2004, Soft-bottom macrobenthic faunal associations and factors affecting species distributions in an Arctic glacial fjord (Kongsfjord, Spitsbergen): Polar Biology, v. 27, p. 155-167.

Wright, D.J., Lundblad, E.R., Larkin, E.M., Rinehart, R.W., Murphy, J., Cary-Kothera, L., and Draganov. K., 2005, ArcGIS benthic terrain modeler, Corvallis, OR, Oregon State University, Davey Jones Locker Seafloor Mapping/Marine GIS Laboratory and National Oceanic and Atmospheric Administration (NOAA) Coastal Services Center (http://www.csc.noaa.gov/products/btm/). 